\title{
Salinity stress induces the production of 2-(2-phenylethyl)chromones and regulates novel classes of responsive genes involved in signal transduction in Aquilaria sinensis calli
}

Xiaohui Wang ${ }^{1}$, Bowen Gao ${ }^{2}$, Xiao Liu', Xianjuan Dong ${ }^{1}$, Zhongxiu Zhang ${ }^{1}$, Huiyan Fan, Le Zhang ${ }^{1}$, Juan Wang ${ }^{1}$, Shepo Shi ${ }^{1 *}$ and Pengfei $\mathrm{Tu}^{1 *}$

\begin{abstract}
Background: Agarwood, is a resinous portion derived from Aquilaria sinensis, has been widely used in traditional medicine and incense. 2-(2-phenylethyl)chromones are principal components responsible for the quality of agarwood. However, the molecular basis of 2-(2-phenylethyl)chromones biosynthesis and regulation remains almost unknown. Our research indicated that salt stress induced production of several of 2-(2-phenylethyl)chromones in $A$. sinensis calli. Transcriptome analysis of $A$. sinensis calli treated with $\mathrm{NaCl}$ is required to further facilitate the multiple signal pathways in response to salt stress and to understand the mechanism of 2-(2-phenylethyl)chromones biosynthesis.

Results: Forty one 2-(2-phenylethyl)chromones were identified from NaCl-treated A. sinensis calli. 93041 unigenes with an average length of $1562 \mathrm{nt}$ were generated from the control and salt-treated calli by Illmunina sequencing after assembly, and the unigenes were annotated by comparing with the public databases including NR, Swiss-Prot, KEGG, COG, and GO database. In total, 18069 differentially expressed transcripts were identified by the transcriptome comparisons on the control calli and calli induced by $24 \mathrm{~h}$ or $120 \mathrm{~h}$ salinity stress. Numerous genes involved in signal transduction pathways including the genes responsible for hormone signal transduction, receptor-like kinases, MAPK cascades, $\mathrm{Ca}^{2+}$ signal transduction, and transcription factors showed clear differences between the control calli and $\mathrm{NaCl}$-treated calli. Furthermore, our data suggested that the genes annotated as chalcone synthases and O-methyltransferases may contribute to the biosynthesis of 2-(2-phenylethyl)chromones.

Conclusions: Salinity stress could induce the production of 41 2-(2-phenylethyl)chromones in A. sinensis calli. We conducted the first deep-sequencing transcriptome profiling of $A$. sinensis under salt stress and observed a large number of differentially expressed genes in response to salinity stress. Moreover, salt stress induced dynamic changes in transcript abundance for novel classes of responsive genes involved in signal transduction, including the genes responsible for hormone signal transduction, receptor-like kinases, MAPK cascades, $\mathrm{Ca}^{2+}$ signal transduction, and transcription factors. This study will aid in selecting the target genes to genetically regulate $A$. sinensis salt-stress signal transduction and elucidating the biosynthesis of 2-(2-phenylethyl)chromones under salinity stress.
\end{abstract}

Keywords: Aquilaria sinensis, 2-(2-phenylethyl)chromones, Salinity stress, Transcriptome Differentially expressed gene, Signal transduction

\footnotetext{
* Correspondence: pengfeitu@163.com

Xiaohui Wang and Bowen Gao are first author. Shepo Shi and Pengfei Tu are corresponding author

${ }^{1}$ Modern Research Center for Traditional Chinese Medicine, Beijing University of Chinese Medicine, Beijing 100029, China

Full list of author information is available at the end of the article
} 


\section{Background}

Aquilaria sinensis is a tropical evergreen tree widely distributed in Fujian, Guangdong, Guangxi and Hainan provinces in China and the other countries such as Vietnam, India, Indonesia, Malaysia, and Thailand [1]. Under stress conditions such as infected by fungi or wounded by wind, lighting, and bited by insects, resinimpregnated heartwoods are slowly forming in the trunk and branches of $A$. sinensis [2-4]. Those resinous heartwoods are commercially called agarwood which has been long-term used as an anti-emetic, digestive, and sedative agent in traditional medicines, and also as incense and peculiar perfume [1]. However, the production of agarwood always takes decades in natural processes, and the natural Aquilaria forests have been seriously destroyed in all countries because of the high value and great demand of agarwood. Therefore, A. sinensis has been listed in Appendix II of the Convention on Internal Trade in Endangered Species of Wild Fauna and Flora [5]. Under these circumstances, Aquilaria trees were cultivated for production of pharmaceutically important and commercially valuble agarwood using artificial methods such as burn-chisel-drill, trunk pruning, and fungi inoculation [3]. However, production of agarwood using artificial methods still takes long time, and the products are always with low quality.

Previous investigations revealed that 2-(2-phenylethyl)chromones are the principal components of argarwood [6-9]. There are more than 100 congeners of 2-(2-phenylethyl)chromones have been reported [10], and many of 2(2-phenylethyl)chromones have potentially pharmacological activities including neuroprotective activity, cytotoxic activity, antibacterial activity, AchE inhibitory, antiinflammatory activity and antioxidatic activity [7, 11-14]. However, the biosynthesis and regulation of 2-(2-phenylethyl)chromones remains completely unknown.

Agarwood-producing plants are timber species which take a considerably long time to grow and the resinous portion is formed inside of the wood. It makes studies using fresh plants difficult and inconvenient. Thus, establishing calli and cell suspension cultures of $A$. sinensis with high production of 2-(2-phenylethyl)chromones, the principal components of agarwood, would be undoubtedly useful for the studies on the mechanism of agarwood formation $[15,16]$. It has been reported that salicylic acid and the crude extracts of fungi could elicit the production of 2-(2-phenylethyl)chromones in the calli and cell suspension cultures of $A$. sinensis $[15,16]$. We are, recently, focusing on exploring the mechanism of agarwood formation, establishment of effective method which can be used to induce the production of 2-(2-phenylethyl)chromones in calli and cell suspension is therefore critically important. Surprisingly, we firstly found that salinity stress induced the production of structurally diverse 2-(2- phenylethyl)chromones in A. sinensis calli and suspension cells, suggesting that 2-(2phenylethyl)chromones might be responsible to salt stress responses. Identification of these 2-(2-phenylethyl)chromones produced in salt-treated calli and suspension cells would be useful for further research on the biological functions of 2-(2-phenylethyl)chromones in stress responses and the mechanism of agarwood formation.

On the other hand, plants integrate complex signal pathways that may cross-talk and diverge at various steps in response to salt stress [17]. High salinity stress induces the biosynthesis of hormones to regulate the expression of specific genes and metabolites including the most important stress-responsive hormone abscisic acid (ABA) [18]. Salinity stress causes water deficit and osmotic stress, enriching the production of ABA in shoots and roots $[19,20]$. The accumulation of ABA can alleviate the inhibitory influence of salinity stress on photosynthesis and growth [21]. Some other phytohormones such as salicylic acid (SA) and brassinosteroids (BR), also participate in plant responses to abiotic stress [22, 23]. Cross-talk among $\mathrm{Ca}^{2+}$ signaling pathways and mitogen-activated protein kinase(MAPK) cascades in salt stress responses have been recently been reported [24-26]. Moreover, novel classes of transcription factor family members viral for signal transduction are induced by salt tress, including bZIP, WRKY, AP2/ERF and NAC families which facilitate the expression levels of various genes that eventually influence plant tolerance of salt stresses [27-31]. Previous research indicated that the transcriptional expression of bZIP genes were enriched in salt-sensitive wheat variety under salt stress, but decreased in salt-tolerant cultivar [28]. In Arabidopsis, salt stress induced the expression of At WRKY8 which directly binds with the promoter of RD29A [29]. Ap2/ERF family members of rice play a significant role in salinity stress response [30]. Over expression of a NAC transcription factor family member in rice and wheat confers salt tolerance [31]. Although traditional forward and genetic approaches can provide valuable insights to salt stress responses, technical limitations may prevent further research. Genome-wide transcriptome analyses have dramatically improved the efficiency of salt stress-related gene discovery [26, 32]. In Arabidopsis, more than $20 \%$ of the transcriptome was observed regulating under salinity stress using transcriptome analysis [32]. However, no systematic consensus on the specific classes of genes corresponding to particular signaling events in response to salt stress has been established so far. Identification and characterization of the key factors for salt stressresponse signaling pathways will be meaningful for further understanding the mechanism of stress responses and the biosynthesis of specific secondary metabolites.

Herein, $\mathrm{NaCl}$ was demonstrated to be an ideal elicitor to induce the production of 2-(2-phenylethyl)chromones 
in $A$. sinensis calli. Using LC-MS-IT-TOF, 41 phenylethylchromones were identified from $\mathrm{NaCl}$-treated $A$. sinensis calli. In order to elucidate the possible mechanisms of salt stress responses of $A$. sinensis, transcriptome sequencing was performed using Illumina sequencing technology, and the data was analyzed to identify the differentially and specifically expressed transcripts of saltregulated genes. Concurrently, the novel classes of $\mathrm{NaCl}-$ responsive genes relevant to signal transduction in response to salt stress were characterized. The results provided valuable insights for further studies on the mechanism of salt stress signaling transduction and agarwood formation.

\section{Results and discussion}

Salt stress induced the production of 2-(2phenylethyl)chromones in A.sinensis calli

To study the effects of different $\mathrm{NaCl}$ concentration on the biosynthesis of 2-(2-phenylethyl)chromones, $75 \mathrm{mM}$, $150 \mathrm{mM}$ and $300 \mathrm{mM} \mathrm{NaCl}$ was applied to the media and 2-(2-phenylethyl)chromones were measured by LC-MSIT-TOF system at 10 days (Fig. 1a). The peaks of tentative 2-(2-phenylethyl)chromones in the BPC profiles of calli extracts indicated that the most species and contents of 2(2-phenylethyl)chromones were induced by $150 \mathrm{mM} \mathrm{NaCl}$
(Fig. 1b). No 2-(2-phenylethyl)chromones were produced in the control calli (no $\mathrm{NaCl}$ supply) (Fig. 1a and b). Our experiments indicated that the accumulation of 2-(2-phenylethyl)chromones kept constantly increasing until four weeks in NaCl-treated calli. Therefore, extracts of A.sinensis calli treated with $150 \mathrm{mM} \mathrm{NaCl}$ for 4 weeks were analyzed by LCMS-IT-TOF. The BPC profiles of A.sinensis calli extracts and mixed standards comprising 33 known 2-(2-phenylethyl)chromones isolated from agarwood are shown in Fig. 1c and d. Forty one 2-(2-phenylethyl)chromones were putatively identified on the basis of their UV and MS data, and 13 of them were unambiguously identified by comparing their retention time $\left(R_{t}\right)$ on HPLC chromatogram, UV and MS data with those of authentic compounds. The other 28 compounds were tentatively identified by their predicted molecular formulas deduced from their HRESIMS data, and further confirmed by comparison of their MS/MS data with those of in literature [10]. All the data of 2-(2-phenylethyl)chromones identified from $\mathrm{NaCl}$-treated $A$. sinensis calli are summarized in Table 1, including $R_{t}$, molecular formula, calculated and experimental molecular weight $(\mathrm{m} / \mathrm{z}$ ), error (a relative error between calculated value and measured value) in generated molecular formula, and MS/MS data. The structures of 13

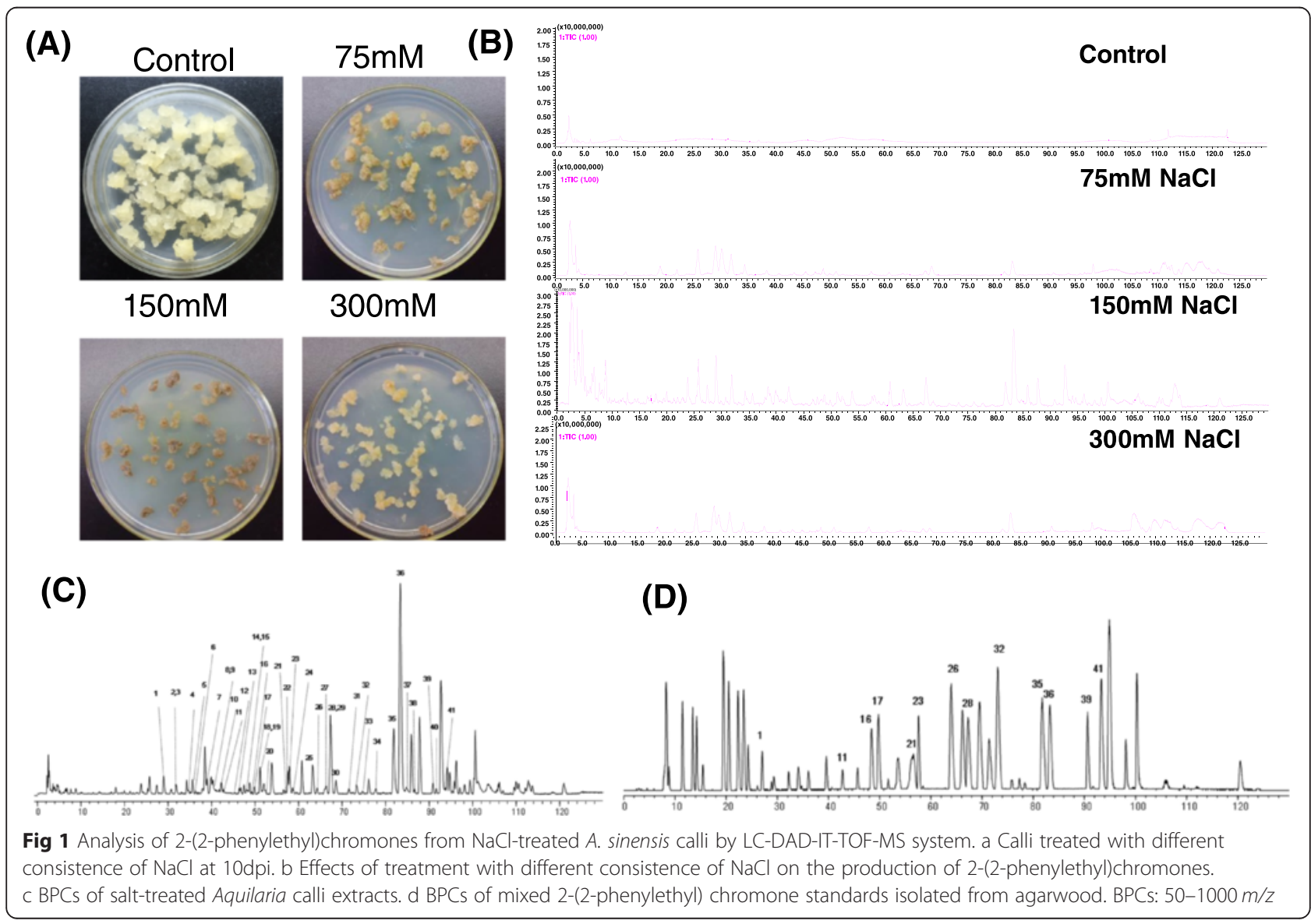


Table 1 Identified and tentative 2-(2-phenylethyl)chromones compounds from the salt-treated Aquilaria calli

\begin{tabular}{|c|c|c|c|c|c|c|}
\hline $\begin{array}{l}\text { Peak } \\
\text { number }\end{array}$ & $\begin{array}{l}t_{R} \\
(\min )\end{array}$ & $\begin{array}{l}\text { Molecular } \\
\text { formula }\end{array}$ & $\begin{array}{l}m / z \\
\text { experimental }\end{array}$ & $\begin{array}{l}\mathrm{m} / \mathrm{z} \\
\text { calculated }\end{array}$ & $\begin{array}{l}\text { Error } \\
\text { (ppm) }\end{array}$ & $\begin{array}{l}\text { IT/MS/MS } \\
\text { fragment }\end{array}$ \\
\hline $1^{*}$ & 29.03 & $\mathrm{C}_{18} \mathrm{H}_{19} \mathrm{O}_{7} \mathrm{Cl}$ & 383.0913 & 383.0892 & 5.48 & 365,137 \\
\hline 2 & 32.12 & $\mathrm{C}_{18} \mathrm{H}_{19} \mathrm{O}_{6} \mathrm{Cl}$ & 367.0920 & 367.0941 & -5.72 & 137 \\
\hline 3 & 32.54 & $\mathrm{C}_{18} \mathrm{H}_{19} \mathrm{O}_{7} \mathrm{Cl}$ & 383.0913 & 383.0892 & 5.48 & 365,137 \\
\hline 4 & 35.01 & $\mathrm{C}_{18} \mathrm{H}_{19} \mathrm{O}_{6} \mathrm{Cl}$ & 367.0955 & 367.0943 & 3.27 & 137 \\
\hline 5 & 35.87 & $\mathrm{C}_{17} \mathrm{H}_{17} \mathrm{O}_{5} \mathrm{Cl}$ & 337.0821 & 337.0837 & -4.75 & 319,195 \\
\hline 6 & 36.59 & $\mathrm{C}_{17} \mathrm{H}_{17} \mathrm{O}_{6} \mathrm{Cl}$ & 353.0820 & 353.0786 & 9.63 & 335 \\
\hline 7 & 39.29 & $\mathrm{C}_{17} \mathrm{H}_{17} \mathrm{O}_{5} \mathrm{Cl}$ & 337.0844 & 337.0837 & 2.08 & 319,195 \\
\hline 8 & 41.32 & $\mathrm{C}_{18} \mathrm{H}_{16} \mathrm{O}_{6}$ & 329.1017 & 329.1020 & -0.91 & 137,122 \\
\hline 9 & 41.48 & $\mathrm{C}_{18} \mathrm{H}_{20} \mathrm{O}_{5}$ & 317.1376 & 317.1384 & -2.52 & 121,299 \\
\hline 10 & 42.09 & $\mathrm{C}_{18} \mathrm{H}_{18} \mathrm{O}_{6}$ & 331.1164 & 331.1176 & -3.62 & 313 \\
\hline $11^{*}$ & 42.99 & $\mathrm{C}_{17} \mathrm{H}_{17} \mathrm{O}_{5} \mathrm{Cl}$ & 337.0821 & 337.0837 & -4.75 & 319,195 \\
\hline 12 & 45.09 & $\mathrm{C}_{17} \mathrm{H}_{14} \mathrm{O}_{5}$ & 299.0904 & 299.0914 & -3.34 & 193,148 \\
\hline 13 & 46.62 & $\mathrm{C}_{19} \mathrm{H}_{18} \mathrm{O}_{6}$ & 343.1173 & 343.1176 & -0.87 & 207, 192 \\
\hline 14 & 48.47 & $\mathrm{C}_{18} \mathrm{H}_{16} \mathrm{O}_{5}$ & 313.1072 & 313.1071 & 0.32 & 206, 191 \\
\hline 15 & 48.99 & $\mathrm{C}_{17} \mathrm{H}_{17} \mathrm{O}_{5} \mathrm{Cl}$ & 337.0844 & 337.0837 & 2.08 & 319,195 \\
\hline $16^{*}$ & 49.37 & $\mathrm{C}_{19} \mathrm{H}_{18} \mathrm{O}_{6}$ & 343.1176 & 343.1176 & 0 & 137 \\
\hline $17^{*}$ & 50.16 & $\mathrm{C}_{18} \mathrm{H}_{16} \mathrm{O}_{5}$ & 313.1072 & 313.1071 & 0.32 & 137 \\
\hline 18 & 51.35 & $\mathrm{C}_{17} \mathrm{H}_{17} \mathrm{O}_{4} \mathrm{Cl}$ & 321.0889 & 321.0888 & 0.31 & 303,212 \\
\hline 19 & 51.77 & $\mathrm{C}_{17} \mathrm{H}_{14} \mathrm{O}_{4}$ & 283.0965 & 283.0965 & 0 & 192 \\
\hline 20 & 52.89 & $\mathrm{C}_{18} \mathrm{H}_{16} \mathrm{O}_{5}$ & 313.1071 & 313.1071 & 0 & 137 \\
\hline $21^{*}$ & 57.51 & $\mathrm{C}_{18} \mathrm{H}_{16} \mathrm{O}_{5}$ & 313.1071 & 313.1071 & 0 & 121, 192 \\
\hline 22 & 58.06 & $\mathrm{C}_{19} \mathrm{H}_{18} \mathrm{O}_{4}$ & 327.1227 & 327.1227 & 0 & 220 \\
\hline $23^{*}$ & 58.48 & $\mathrm{C}_{17} \mathrm{H}_{14} \mathrm{O}_{4}$ & 283.0965 & 283.0965 & 0 & 192 \\
\hline 24 & 58.98 & $\mathrm{C}_{20} \mathrm{H}_{20} \mathrm{O}_{6}$ & 357.1339 & 357.1333 & 1.68 & 137,220 \\
\hline 25 & 63.28 & $\mathrm{C}_{18} \mathrm{H}_{16} \mathrm{O}_{4}$ & 297.1123 & 297.1121 & 0.67 & 121 \\
\hline $26^{*}$ & 64.80 & $\mathrm{C}_{17} \mathrm{H}_{14} \mathrm{O}_{3}$ & 267.1011 & 267.1016 & -1.87 & 107 \\
\hline 27 & 66.05 & $\mathrm{C}_{18} \mathrm{H}_{15} \mathrm{O}_{5} \mathrm{Cl}$ & 347.0681 & 347.0681 & 0 & 137 \\
\hline $28^{*}$ & 67.35 & $\mathrm{C}_{19} \mathrm{H}_{18} \mathrm{O}_{5}$ & 327.1229 & 327.1227 & 0.61 & 137 \\
\hline 29 & 67.78 & $\mathrm{C}_{18} \mathrm{H}_{16} \mathrm{O}_{4}$ & 297.1126 & 297.1121 & 1.68 & 206, 191 \\
\hline 30 & 69.14 & $\mathrm{C}_{18} \mathrm{H}_{16} \mathrm{O}_{4}$ & 297.1123 & 297.1121 & 0.67 & 107,191 \\
\hline 31 & 71.68 & $\mathrm{C}_{19} \mathrm{H}_{18} \mathrm{O}_{5}$ & 327.1127 & 327.1127 & 0 & 137 \\
\hline $32^{*}$ & 73.00 & $\mathrm{C}_{17} \mathrm{H}_{14} \mathrm{O}_{3}$ & 267.1016 & 267.1016 & 0 & 176 \\
\hline 33 & 75.58 & $\mathrm{C}_{19} \mathrm{H}_{18} \mathrm{O}_{6}$ & 343.1176 & 343.1176 & 0 & 137,167 \\
\hline 34 & 77.18 & $\mathrm{C}_{19} \mathrm{H}_{16} \mathrm{O}_{5}$ & 325.1063 & 325.1071 & -2.46 & 151 \\
\hline $35^{*}$ & 82.33 & $\mathrm{C}_{20} \mathrm{H}_{20} \mathrm{O}_{5}$ & 341.1381 & 341.1384 & -0.88 & 121,220 \\
\hline $36^{*}$ & 83.90 & $\mathrm{C}_{19} \mathrm{H}_{18} \mathrm{O}_{4}$ & 311.1277 & 311.1278 & -0.32 & 181,220 \\
\hline 37 & 85.35 & $\mathrm{C}_{19} \mathrm{H}_{18} \mathrm{O}_{6}$ & 343.1176 & 343.1176 & 0 & 121 \\
\hline 38 & 86.96 & $\mathrm{C}_{18} \mathrm{H}_{16} \mathrm{O}_{5}$ & 313.1071 & 313.1071 & 0 & 222 \\
\hline $39^{*}$ & 91.24 & $\mathrm{C}_{17} \mathrm{H}_{13} \mathrm{O}_{3} \mathrm{Cl}$ & 301.0625 & 301.0626 & -0.33 & 210,170 \\
\hline 40 & 92.32 & $\mathrm{C}_{17} \mathrm{H}_{14} \mathrm{O}_{2}$ & 251.1067 & 251.1067 & 0 & \\
\hline $41^{*}$ & 93.55 & $\mathrm{C}_{19} \mathrm{H}_{18} \mathrm{O}_{4}$ & 311.1277 & 311.1278 & -0.32 & 121,190 \\
\hline
\end{tabular}

*: 2-(2-phenylethyl) chromone derivatives identified with standards (1)8-Chloro-5,6,7-trihydroxy-2-(3-hydroxy-4-methoxyphenethyl)-5,6,7,8-tetrahydro4H-chromen-4-one; (11) 8-Chloro-2-(2-phenylethyl)-5,6,7-trihydroxy-5,6,7,8tetrahydrochromone; (16) 7-Hydroxy-6-methoxy-2-[2-(3'-hydroxy-4'methoxyphenyl)ethyl]chromone; (17) 6-Hydroxy-2-[2-(4'-hydroxy-3'methoxyphenyl)ethenyl]chromone.; (21) Oxidoagarochromone B; (23) Oxidoagarochromone $A$; (26) 2-(2-4'- hydroxyphenylethyl)chromone; (28) 6Methoxy-2-[2-(3-methoxy-4-hydroxyphenyl)ethyl]chromone; (32) AH3: 6-Hydroxy-2(2-phenylethyl)chromone; (35) AH8: 6,7-Dimethoxy-2-[2-(4-methoxyphenyl)ethyl]chromone; (36) AH6: 6,7-Dimethoxy-2(2-phenylethyl)chromone; (39) 6-Hydroxy-8chloro -2-(2-phenylethyl) chromone;

(41) 6-Methoxy-2-[2-(3'-methoxyphenyl)ethyl]chromone

unambiguously identified 2-(2-phenylethyl)chromones from $\mathrm{NaCl}$-treated A.sinensis calli are represented in Fig. 2. Previous studies showed that crude extracts of Melanotus flavolives (B.etc.) Sing. only induced four 2-(2-phenylethyl)chromones in A.sinensis cell suspension cultures [15]. In this study, we firstly used the salt treatment which is the most important abiotic stress to produce a lot of 2(2-phenylethyl)chromones. These results indicated that salt stress was the effective method to induce the production of 2-(2-phenylethyl)chromones in calli.

\section{Optimization of Illumina sequencing timing}

Previous experiments indicated that the cell were almost died at 10 days, in order to determine the best time for tanscriptome analysis, cell activity and 2-(2-phenylethyl)chromone accumulation in calli treated with $150 \mathrm{mM}$ $\mathrm{NaCl}$ was investigated at 0 h, 24 h,72 h, 120 h, 168 h and $216 \mathrm{~h}$. The results revealed that the activities of the cells treated with $\mathrm{NaCl}$ decreased significantly at $24 \mathrm{~h}$ and $120 \mathrm{~h}$, and the activities reached to $30 \%$ and $5 \%$ of the control, respectively (Fig. 3a). We also discovered that the main 2-(2-phenylethyl)chromones detected from the calli were 6,7-dimethoxy-2-[2-(4'-methoxyphenyl)ethyl] chromone (compound 35) and 6,7-dimethoxy-2-(2-phenylethyl) chromone (compound 36) during the early inducing period (Fig. 3b). These two compounds are also the main 2-(2-phenylethyl)chromones in agarwood and kept increasing in the wood tissues of $A$. sinensis with the time of fungal infection [27]. Therefore, the occurrence of these two 2-(2-phenylethyl)chromones could be used as an important indicator for studies on the formation of agarwood. Compound 36 was firstly detected in the $\mathrm{NaCl}-$ treated calli for $24 \mathrm{~h}$ (Fig. 3b), and then the contents of compounds 35 and 36 increased constantly. The production of 2-(2-phenylethyl)chromones 35 and 36 increased remarkably at $120 \mathrm{~h}$ (Fig. 3b), continuously, high-quality and sufficient RNA could be isolated from the calli which were treated with $150 \mathrm{mM} \mathrm{NaCl}$ until $120 \mathrm{~h}$. Therefore, three cDNA libraries from the control and induced A.sinensis calli treated with salt at $24 \mathrm{~h}$ and $120 \mathrm{~h}$ were constructed using Illumina sequencing. 
<smiles>[R]c1ccc(CCC2=CC(=O)C3C(O2)[C@H](O)[C@@H](O)[C@@H](O)[C@@H]3Cl)cc1[R]</smiles>

$\begin{array}{cccc} & \mathrm{R}_{1} & \mathrm{R}_{2} & \mathrm{MW} \\ 1 & \mathrm{OH} & \mathrm{OCH}_{3} & 382 \\ 11 & \mathrm{H} & \mathrm{H} & 336\end{array}$<smiles>[R]c1ccc(CCc2cc(=O)c3c(o2)C2O[C@H]2[C@H]2O[C@@H]32)cc1</smiles>

$\begin{array}{ccc} & \text { R } & \text { MW } \\ 21 & \text { OCH }_{3} & 312 \\ 23 & \text { H } & 282\end{array}$<smiles>[R]c1ccc(CCc2cc(=O)c3cc([R])c([R])c([R])c3o2)cc1[R]</smiles>

$\begin{array}{lllllll} & \mathrm{R}_{1} & \mathrm{R}_{2} & \mathrm{R}_{3} & \mathrm{R}_{4} & \mathrm{R}_{5} & \mathrm{MW} \\ 16 & \mathrm{OCH}_{3} & \mathrm{OH} & \mathrm{H} & \mathrm{OH} & \mathrm{OCH}_{3} & 342 \\ 17 & \mathrm{OH} & \mathrm{H} & \mathrm{H} & \mathrm{OCH}_{3} & \mathrm{OH} & 312 \\ 26 & \mathrm{H} & \mathrm{H} & \mathrm{H} & \mathrm{H} & \mathrm{OH} & 266 \\ 28 & \mathrm{OCH}_{3} & \mathrm{H} & \mathrm{H} & \mathrm{OCH} & \mathrm{OH} & 326 \\ 32 & \mathrm{OH} & \mathrm{H} & \mathrm{H} & \mathrm{H} & \mathrm{H} & 266 \\ 35 & \mathrm{OCH} & \mathrm{OCH} & \mathrm{H} & \mathrm{H} & \mathrm{OCH} & 340 \\ 36 & \mathrm{OCH}_{3} & \mathrm{OCH} & \mathrm{H} & \mathrm{H} & \mathrm{H} & 310 \\ 39 & \mathrm{OH}_{3} & \mathrm{H} & \mathrm{Cl} & \mathrm{H} & \mathrm{H} & 300 \\ 41 & \mathrm{OCH}_{3} & \mathrm{H} & \mathrm{H} & \mathrm{OCH} & \mathrm{H} & 310\end{array}$

Fig. 2 The structures of 2-(2-phenylethyl)chromones identified with the standards

Transcriptome sequence assembly and annotation of the unigenes

Three cDNA libraries which were generated with mRNA from control calli, and calli induced by $150 \mathrm{mM} \mathrm{NaCl}$ at $24 \mathrm{~h}$ and $120 \mathrm{~h}$ were assembled and annotated. A total of 68962 124, 70631522 and 70951038 clean reads for control (designated control) and induced calli which treated with $150 \mathrm{mM} \mathrm{NaCl}$ for $24 \mathrm{~h}$ (designated induced$24 \mathrm{~h}$ ) and $120 \mathrm{~h}$ (designated induced-120 h) were generated after removal of the adaptors and unknown or lowquality reads, giving a total of 6206591160 nt, 6356836 $980 \mathrm{nt}$ and $6385593420 \mathrm{nt}$ for the control, induced-24 h and induced-120 h library (Table 2). After complete assembly of the reads, 104 316, 99429 and 98697 contigs with median contig size of $476 \mathrm{nt}, 466 \mathrm{nt}$ and $474 \mathrm{nt}$, were yielded from the control, induced-24 $\mathrm{h}$ and induced-120 $\mathrm{h}$ library, respectively. Further assembly analysis showed that the control, induced-24 $\mathrm{h}$ and induced-120 h library consisted of 91835,83674 and 83674 unigenes (Table 2), respectively. However, there were 93041 unigenes with a mean length of $1562 \mathrm{nt}$ were generated from three libraries. The length distribution of unigenes was shown in the Additional file 1: Table S1.

Functions of the unigenes were annotated by BLASTX based on sequence similarity to sequences in the public databases, including NR, Swiss-Prot, KEGG, COG and GO database, and then aligned to the nucleotide database NT $\left(E\right.$-value $\left.\leq 1.0 \mathrm{e}^{-5}\right)$ by BLASTN. There were 29387 unigenes matched to one or more database and a total of 65585 unigenes were annotated. NR classification results 


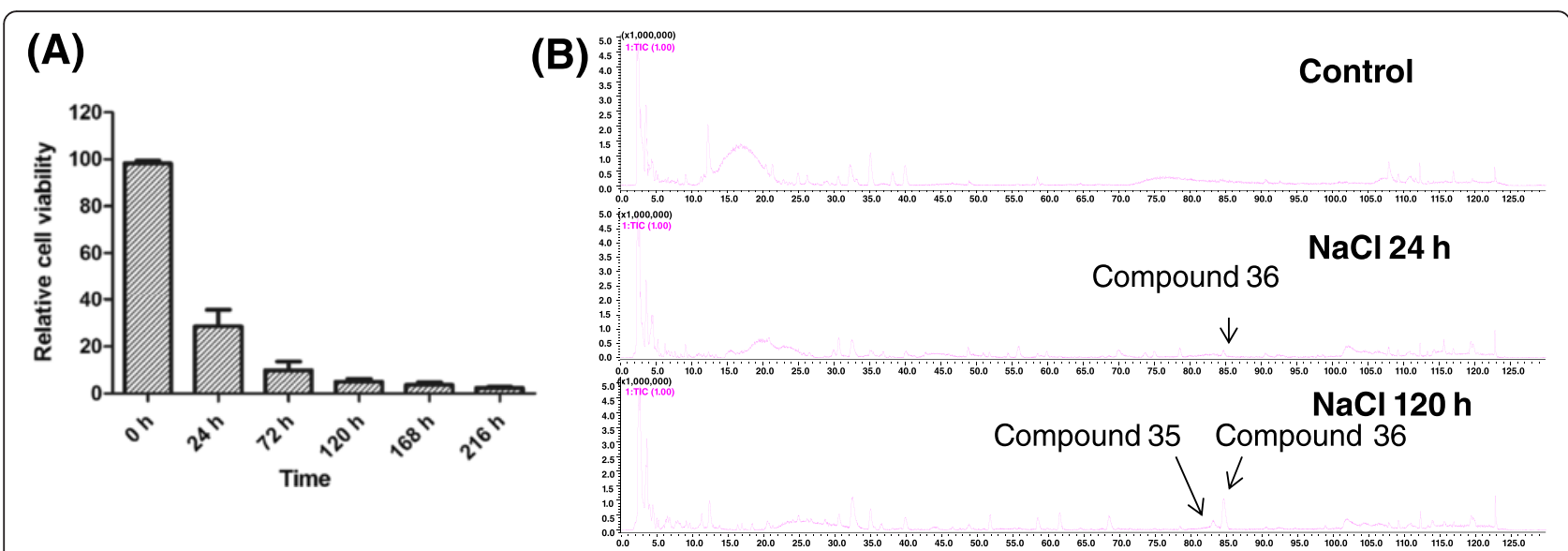

Fig. 3 Effects of $\mathrm{NaCl}$ treatment on the cell activity of A. sinensis calli and production of 2-(2-phenylethyl)chromones at different time points. a Relative cell activity of calli exposed to $150 \mathrm{mM} \mathrm{NaCl}$ treatment. Values was means standard error $(n=3)$. Means denoted by the same letter did not significantly differ at $P<0.05$ according to Duncan's multiple range tests. $\mathbf{b}$ BPCs of $150 \mathrm{mM} \mathrm{NaCl}$ treated A. sinensis calli extracts at 0 h, 24 h and $120 \mathrm{~h}$

revealed that there were 64092 unigenes matched to this database and the unigenes of A.sinensis shared $23.2 \%$ and $20.9 \%$ similarity to the homologs with Vitis vinifera and Ricinus communis by BLASTX annotation, followed $15.5 \%$ and $14.5 \%$ for Populus balsamifera and Amygdalus persica, respectively (Fig. 4). To further classify the function of the total unigenes, the unigenes were annotated by the GO, COG and KEGG database. GO analysis indicated that the unigenes were grouped into three main categories (biological process, cellular component and molecular function), which together include 55 function classes (Additional file 2: Figure S1; See supporting information). 29395 unigenes had COG annotations and were distributed in 25 clusters including the largest group "General function prediction", followed by the group of "replication, recombination and repair" and "transcription" (Additional file 3: Figure S2; See supporting information). Gene annotation and pathway mapping in KEGG database indicated that 40552 unigenes were distributed in 128 KEGG pathways. The top three KEGG pathways which include the largest number of unigenes were metabolic pathways,

Table 2 Summary statistics for sequencing and sequence assembly for three libraries prepared from the control and salt-treated calli

\begin{tabular}{llll}
\hline Features & Control & Induced-24 h & Induced-120 h \\
\hline Total clean Reads & 68962124 & 70631522 & 70951034 \\
Total Clean Nucleotides (nt) & 6206591 & 6385593 & 6356836980 \\
& 160 & 420 & \\
Unigenes & 91835 & 83674 & 83870 \\
Total Length (nt) & 117782 & 95610624 & 101385512 \\
Mean Length (nt) & 876 & & \\
N50 & 1283 & 1143 & 1209 \\
\hline
\end{tabular}

biosynthesis of secondary metabolites and plant-pathogen interaction (Additional file 4: Table S2; See supporting information).

With the advent of sequencing, genome-wide analyses become available in many plant species and have significantly improved the efficiency of gene discovery. However, no genomic data is available for A.sinensis. The Illumina technology have been the first choice in field of transcriptome sequencing studies since 2012, owing to the increasing in sequencing length of reads to $150 \mathrm{bp}$ or more [33]. In this study, we carried out de novo transcriptome assembly of A.sinensis calli. To date, the transcriptome information of A.sinensis was acquired by Roche 454 GS platform [2]. However, our de novo transcriptome analysis generated greater depth of sequencing, obtaining more complete coverage of the transcriptome comparing with 454 pyrosequencing in previous study. In this study, our transcriptome assembly was compared with the previous published transcriptomes using 454 pyrosequencing [2]. As shown in Additional file 1: Table S1, more than $57 \%$ unigenes were greater than $1 \mathrm{~kb}$, and more than $73 \%$ unigenes were greater than $500 \mathrm{bp}$. However, over $70 \%$ of the unigenes assembled by 454 GS platform were $200 \mathrm{bp}$ and $600 \mathrm{bp}$ long. These results indicated that our seq-RNA assembly captured larger portion of the transcriptome of A.sinensis. Owing to lack of genomic resources for A.sinensis, the proportions of unigenes which significantly corresponding to the known proteins in GenBank were considered as another useful metric. Nearly $68.89 \%$ of our unigenes had matched in NR protein database, and this value was higher than $42.8 \%$ reported in 454 GS platform assembly [2]. Thus, the de novo assembly of mRNA-seq will significantly improve the genome annotation of A.sinensis and be used for further study on the functional members of gene families. 


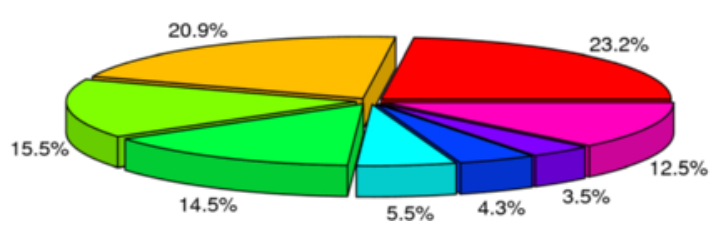

- Vitis vinifera

= Ricinus communis

- Populus balsamifera subsp. trichocarpa

- Amygdalus persica

- Fragaria vesca subsp. vesca

- Glycine max

- Cucumis sativus

- other

Fig. 4 Species distribution of unigenes by BLASTX annotation. The figure indicated species distribution of unigenes BLASTX annotation with a cut-off E-value of 1.0E $E^{5}$. Different color showed different species

\section{Functional analysis of differentially expressed genes}

To investigate the gene expression changes in response to salinity stress, the gene expression level was measured in fragment per kilobase of exon per million fragments mapped $($ FRKM) and the false discovery rate $[$ FDR] $<0.001$ and the absolute value of $\log 2$ Ratio $\geq 1$ was used as a threshold to estimate the statistical significance of transcript expression. A total of 18069 differentially expressed genes were identified, including 454, 940 and 220 expressed uniquely in control, induced-24 h and induced-120 h libraries, respectively; 10881 unigenes were expressed in three libraries but at different levels (Fig. 5a). After induced by salt treatment for $24 \mathrm{~h}, 5313$ genes were induced while 10266 genes were down-regulated. However, 2898 genes were up-regulated and 6268 genes were down-regulated after induced by salt stress for $120 \mathrm{~h}$ (Fig. 5b).

The differentially expressed genes from the control and induced libraries were organized in functional categories by GO enrichment analysis (Fig. 6). According to the sequence homologies, the differentially expressed genes were assigned to three principal categories: biological process, cellular component and molecular function, which contained 22, 17 and 14 functional groups. Among these groups, the induced-24 h VS control and induced$120 \mathrm{~h}$ VS control comparisons had similar distribution of gene functions in biological process, cellular component and molecular function. However, the GO terms "cell periphery", "extracellular region" and "external encapsulating structure" were significantly enriched after inducing by salt stress for $24 \mathrm{~h}$, whereas "cell periphery", "anchored to membrane" and "regulation of meristem growth" were primarily enriched after inducing by salt stress for $120 \mathrm{~h}$ (Fig. 6). We also found that a high percentage of transcripts after inducing by salt for $24 \mathrm{~h}$ and $120 \mathrm{~h}$ fell into the functional groups: "cell”, "cell part", "cellular process", "metabolic process" and "organelle part"(Fig. 6). To further analysis the function of differentially expressed transcripts, the differentially expressed genes were mapped in the KEGG database. The KEGG analysis indicated that 6621 DEGs with pathway annotation were distributed in 125 KEGG pathways after salt treatment for $24 \mathrm{~h}$, and among these pathways, 31 pathways with P-value $\leq 0.01$ were significantly influenced (Additional file 5: Table S3; See supporting information). After inducing $120 \mathrm{~h}$ by $150 \mathrm{mM} \mathrm{NaCl}, 4168$ annotated DEGs transport involved in 123 KEGG pathways, and 40 pathways with P-value $\leq 0.01$ were significantly enriched (Additional file 6: Table S4; See supporting information). Notably, remarkable enrichment was observed in plant-pathogen interaction pathway, stilbenoid, diarylheptanoid and gingerol biosynthesis pathway,
(A)

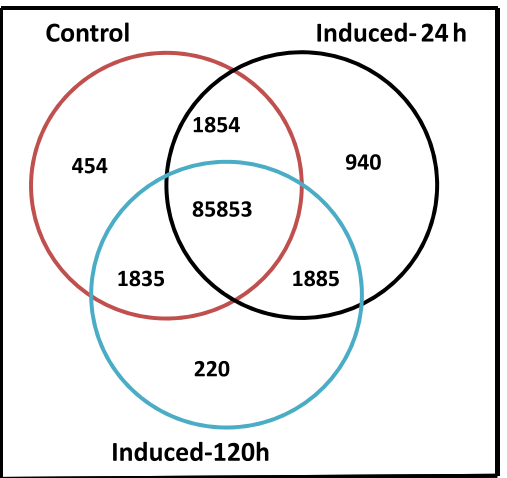

(B)

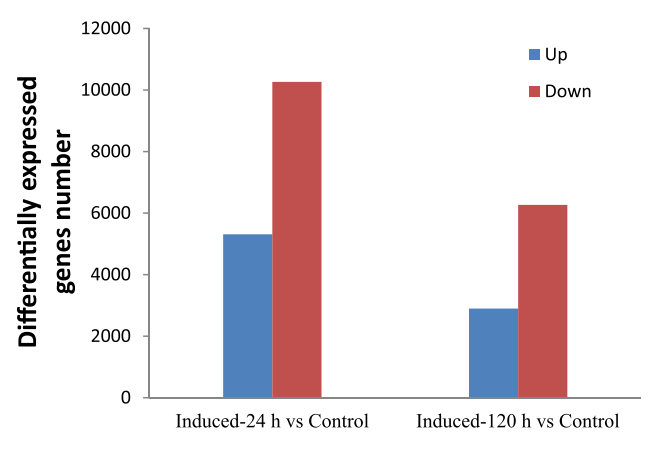

Fig. 5 Comparison of the unigenes expressed in the salt-treated and control labraries. a Venn diagram showing the unigenes expressed in the control and salt-treated calli. b Changes in gene expression profiles among the control, induced-24 h and induced-120 h calli libraries. The number of up-regulated and down-regulated DEGs between the control and induced-24 h, control and induced-120 h libraries were shown. We judged the significance of gene expression difference with the threshold FDR(False Discovery Rate) $\leq 0.001$ and the absolute value of $\log _{2}$ Ratio $\geq 1$ 


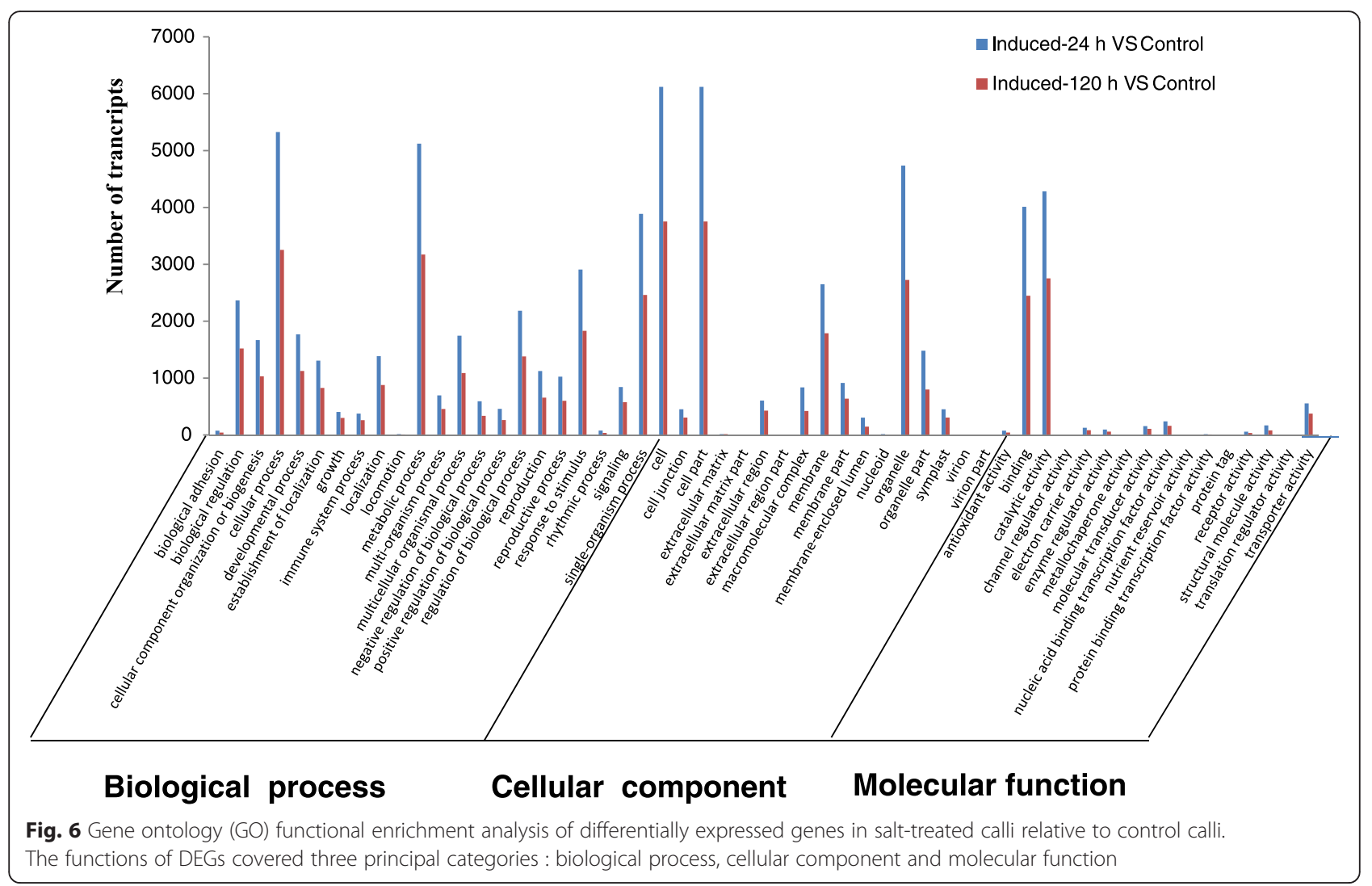

plant hormone signal transduction pathway and pheylpropanoid biosynthesis after inducing by salt for $24 \mathrm{~h}$ and $120 \mathrm{~h}$ (Table 3). These results suggested that the transcriptome of A.sinensis calli was remarkably affected in response to salinity stress and provided resources for screening genes required for salinity stress and agarwood formation.

\section{Confirmation of differentially expressed candidate} transcripts by quantitative real-time PCR (qRT-PCR)

To confirm the reliability of the RNA-seq results, a total of 26 candidate genes were selected for qRT-PCR analysis with specific primers (Additional file 7: Table S5; See supporting information). The analysis results suggested that all 26 DEGs selected had the same expression trends as Illumia-Solexa sequencing (Fig. 7a). For

Table 3 Significantly enriched KEGG pathways induced in A.sinensis in response to salt stress

\begin{tabular}{lll}
\hline \multirow{2}{*}{ Pathway category } & \multicolumn{2}{l}{ Enriched P-value* } \\
\cline { 2 - 3 } & $\begin{array}{l}\text { Induced-24 h } \\
\text { VS Control }\end{array}$ & $\begin{array}{l}\text { Induced-120 h } \\
\text { VS Control }\end{array}$ \\
\hline $\begin{array}{l}\text { Plant-pathogen interaction pathway } \\
\begin{array}{l}\text { Stilbenoid, diarylheptanoid and } \\
\text { gingerol biosynthesis }\end{array}\end{array}$ & $\begin{array}{l}2.35 \mathrm{e}-44 \\
\text { Plant hormone signal transduction }\end{array}$ & $\begin{array}{l}1.71 \mathrm{e}-65 \\
\text { Pheylpropanoid biosynthesis }\end{array}$ \\
\hline
\end{tabular}

example, both qRT-PCR and RNA-seq analysis indicated that the Mitogen-activated protein kinase kinase kinase (MAPKKKA, MAPKKK2 and MAPKKK3), calmodulin, WRKY transcription factors (WRKY39, WRKY40 and WRKY75), caffeoyl-CoA-O-methyltransferase, and chalcone synthase $1(\mathrm{CHS} 1)$ were significantly more highly expressed in salt-treated calli compared with the control calli. Otherwise, suppression of auxin influx carrier and auxin response factor 4 by salt treatment indicated by RNA-seq analysis was verified by qRT-PCR analysis. Furthermore, a high correlation $\left(R^{2}=0.8443\right)$ was detected between RNA-seq and qRT-PCR (Fig. 7b). These results demonstrated the changes in the gene expression analyzed by RNA-seq reflecting the practical transcriptome difference between the control and salt-treatment calli.

\section{Salinity stress induced a complex hormone signal pathway}

Salinity stress in plant induced hormone-independent signaling pathway and hormone biosynthesis [34]. KEGG enrichment analysis showed that 2042 out of 40402 A.sinensis calli genes annotated as being related to hormone signal transduction pathways were detected in three libraries and 396 of these genes were differentially expressed in calli under salinity stress. Among the hormone signal transduction related DEGs, 130 were upregulated and 202 down-regulated at $24 \mathrm{~h}$ induced by 


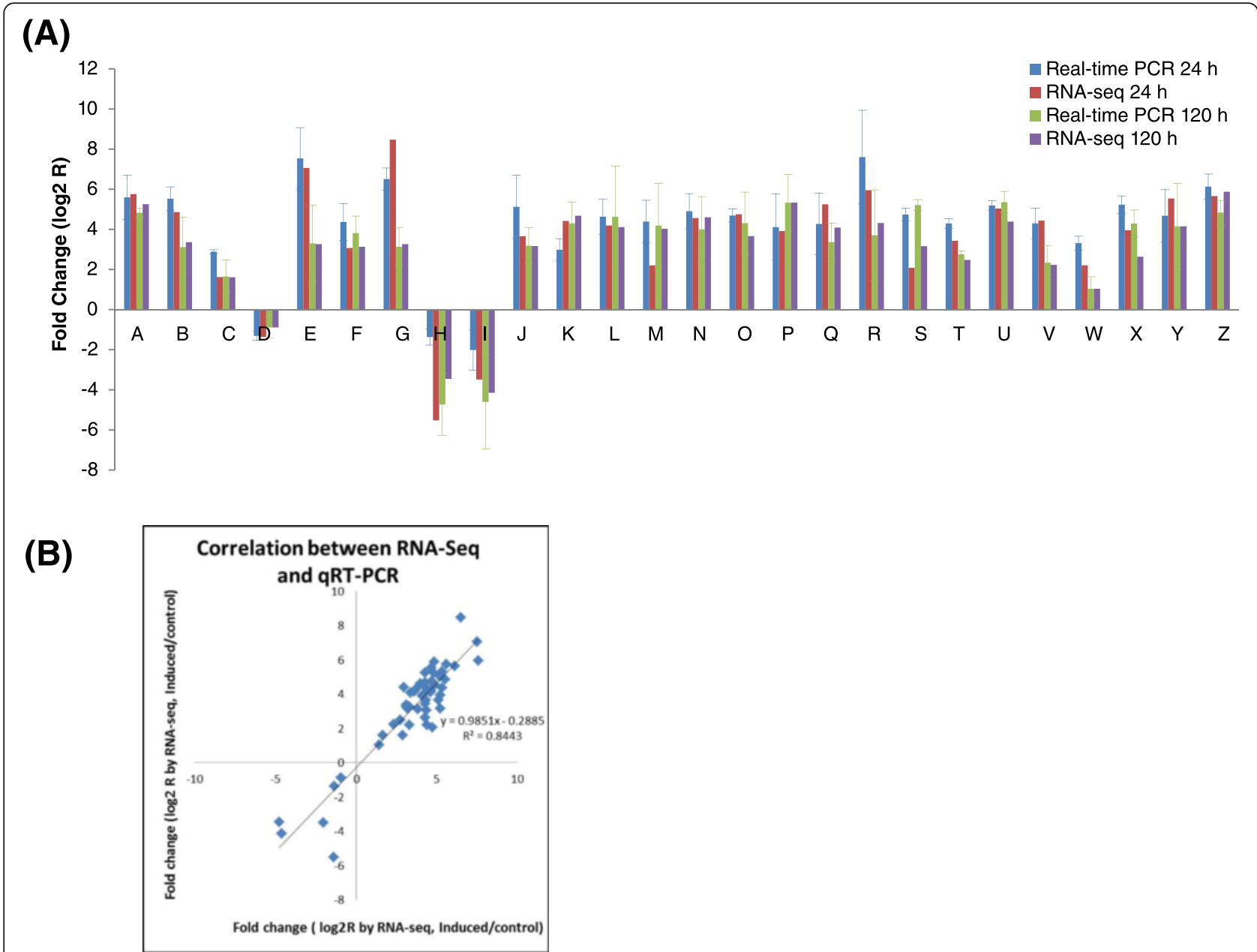

Fig. 7 Validation of the relative expression levels of differential expression transcripts by quantitative RT-PCR (qRT-PCR) analysis. a Expression profiles of the selected DEGs in the salt-treated calli relative to the control calli, as determined by qRT-PCR(24 h: blue; 120 h:green) and RNA-seq(24 h:red; 120 h: purple). The $x$-axis indicated the annotation of the selected DEGs. The $y$-axis indicated the normalized expression level of the genes. A: Calmodulin 1; B: Calcium-binding protein CML37; C: Calcium-dependent protein kinase 10; D: Calcium-dependent protein kinase 13-like; E: Mitogen-activated protein kinase kinase kinase A; F: Mitogen-activated protein kinase kinase kinase 2; G: Mitogen-activated protein kinase kinase kinase 2; H: Auxin influx carrier; l: Auxin response factor 4; J: G-type lectin S-receptor-like serine/threonine-protein kinase; K: Cysteine-rich receptor-like protein kinase 25; L: LRR receptor-like serine/ threonine-protein kinase FLS2; M: WRKY transcription factor 75; N: WRKY transcription factor 40; O:WRKY transcription factor 29; P: Ethylene-responsive transcription factor ERF(AP2/ERF); Q: MYB-related protein MYB4; R: MYB superfamily protein 1; S: Methyltransferase PMT15; T: Caffoyl-CoA-O-

methyltransferase; U: Caffeic acid 3-O-methyltransferase; V: Chalcone synthase; W: Respiratory burst oxidase homolog protein A; X:Respiratory burst oxidase homolog protein B; Y: Respiratory burst oxidase homolog protein D; Z: Pathogenesis-related protein STH-2. The transcriptional level of the selected genes was performed by qRT-PCR with three biological replications and action was used as an internal reference. Error barsrepresent the standard deviations of qRT-PCR signals $(n \geq 3)$. $\mathbf{b}$ Correlation of the expression ratio of selected DEGs analyzed by qRT-PCR and RNA-seq

salt treatment, while 74 of genes were up-regulated and 163 were down-regulated at $120 \mathrm{~h}$ induced by salt treatment, a total of 175 were co-regulated in $24 \mathrm{~h}$ and $120 \mathrm{~h}$ for salt stress. Hierarchical clustering of the differentially expressed hormone-related genes indicated overall difference at control, $24 \mathrm{~h}$ and $120 \mathrm{~h}$ in response to salt stress (Fig. 8a). Pathway enrichment analysis indicated that 8 of hormone-independent signaling pathways including ABA, cytokinine, auxin, brassinosteroid, jasmonic acid, salicylic acid, ethylene and gibberellin pathways were induced in calli after salt treatment for $24 \mathrm{~h}$ and $120 \mathrm{~h}$ (Table 4).
However, more than $70 \%$ of DEGs related to auxin, cytokinine and ethylene pathways were down-regulated, whereas more than $50 \%$ of DEGs required for gibberellin, salicylic acid were up-regulated. These results indicated that salinity stress induced a complex hormone signal transduction pathway.

High salinity elicits rapid and constantly changes in gene expression overlapping with responses to the hormone [34]. Abscisic acid is an essential hormone that mediates plant growth in response to salinity stress through regulating the expression of many genes which encode various 


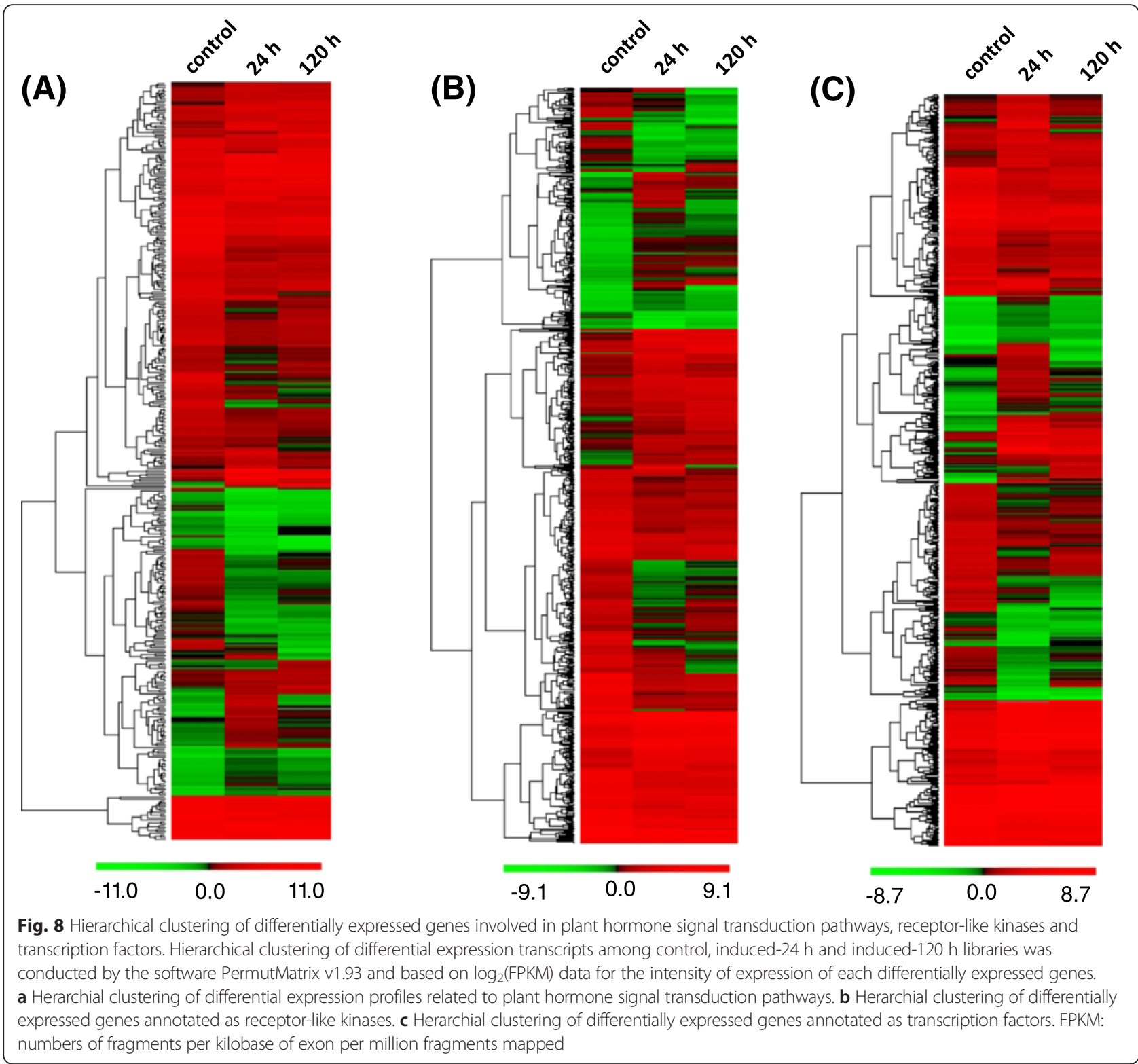

proteins vital for biochemical and physiological processes. ABA mediates the salt-stress signaling transduction pathway through the important signaling components, including the $\mathrm{ABA}$ receptor PYR/PYL family proteins, the group of protein phosphate $2 \mathrm{C}$, the members of serine/threonine -protein kinase SnRK2, and ABA responsive element binding proteins [35, 36]. In A.sinensis calli during salinity stress, the proteins of ABA receptor PYR/PYL family, phosphate $2 \mathrm{C}$ family and $\mathrm{ABA}$ responsive element binding proteins family showed significantly differential expression patterns, however, the transcripts which annotated as serine/threonine-protein kinase SnRK2 showed no obvious changes(Table 4). The comparative analysis of expression profiles indicated a crosstalk between salt stress and ABA signal pathway. As well as the well-known stress- responsive $\mathrm{ABA}$, other phytohormones were also responsible for salt stress. Recent studies indicated that alterations in cytokinine signaling influenced plant response to abiotic stress, seed germination, cell division, and floral initiation [37, 38]. In Arabidopsis, endogenous cytokinin overproduction decreased salt stress resistance, however, low cytokinin levels promoted salt-induced senescence in tomato [39]. Our transcriptome analysis indicated that the majority of receptor kinases and response regulators responsible for cytokinine signal transduction were significantly decreased under salt treatment (Table 4). For example, the majority of changed A.sinensis CRE1 genes which are the important cytokinin receptors were downregulated under salt stress. Down-stream genes such as ARR-B genes indicated both up- or down-regulated under 
Table 4 The number of differentially expressed genes involved in in the hormone signal transduction pathways

\begin{tabular}{|c|c|c|c|c|c|c|}
\hline \multirow[t]{3}{*}{ Family, group, or pathway } & \multicolumn{6}{|c|}{ Number of unigenes } \\
\hline & \multirow[t]{2}{*}{ Total DEGs } & \multicolumn{2}{|l|}{ Induced-24 h } & \multicolumn{2}{|c|}{ Induced-120 h } & \multirow{2}{*}{$\begin{array}{l}\text { Co-regulated } \\
\text { unigenes }\end{array}$} \\
\hline & & Up-unigenes & Down-unigenes & Up-unigenes & Down-uigenes & \\
\hline Abscisic acid & 53 & 19 & 24 & 16 & 19 & 25 \\
\hline Abscisic acid receptor PYR/PYL family & 4 & 1 & 2 & 2 & 1 & 2 \\
\hline Protein phosphatase $2 \mathrm{C}$ & 41 & 16 & 17 & 13 & 13 & 18 \\
\hline $\mathrm{ABA}$ responsive element binding factor & 8 & 2 & 5 & 1 & 5 & 5 \\
\hline Cytokinine & 79 & 16 & 48 & 2 & 51 & 38 \\
\hline Arabidopsis histidine kinase 2/3/4(CRE1) & 38 & 0 & 35 & 0 & 34 & 31 \\
\hline Histidine-containing phosphotransfer protein (AHP) & 2 & 0 & 2 & 0 & 0 & 0 \\
\hline Two-component response regulator ARR-B family & 34 & 16 & 9 & 2 & 13 & 6 \\
\hline Two-component response regulator ARR-A family & 5 & 0 & 2 & 0 & 4 & 1 \\
\hline Auxin & 75 & 16 & 47 & 9 & 39 & 41 \\
\hline Auxin influx carrier & 7 & 1 & 6 & 1 & 6 & 7 \\
\hline Auxin-responsive protein IAA & 18 & 5 & 12 & 2 & 11 & 11 \\
\hline Transport inhibitor response 1 & 1 & 0 & 1 & 0 & 1 & 0 \\
\hline Auxin response factor(ARF) & 31 & 0 & 25 & 0 & 19 & 13 \\
\hline Auxin responsive GH3 gene family & 6 & 3 & 2 & 3 & 2 & 4 \\
\hline SAUR family protein & 12 & 7 & 4 & 3 & 4 & 6 \\
\hline Brassinoteroid & 61 & 31 & 23 & 27 & 13 & 31 \\
\hline Protein brassinosteroid insensitive 2(BIN2) & 1 & 1 & 0 & 0 & 0 & 0 \\
\hline Brassinosteroid resistant 1/2 & 4 & 0 & 4 & 0 & 4 & 4 \\
\hline Xyloglucan:xyloglucosyl transferase TCH4 & 5 & 4 & 1 & 1 & 0 & 0 \\
\hline Cyclin D3 & 5 & 5 & 0 & 4 & 0 & 3 \\
\hline BR-signaling kinase & 3 & 1 & 2 & 0 & 0 & 0 \\
\hline Brassinosteroid insensitive1-associated receptor kinase 1 & 41 & 19 & 15 & 21 & 8 & 22 \\
\hline Serine/threonine-protein kinase BRI1 & 2 & 1 & 1 & 1 & 1 & 2 \\
\hline Jasmonic acid & 36 & 19 & 12 & 7 & 11 & 13 \\
\hline Coronatine-insensitive protein 1 & 1 & 0 & 1 & 0 & 1 & 1 \\
\hline Jasmonate ZIM domain-containing protein(JAZ) & 9 & 5 & 2 & 4 & 2 & 3 \\
\hline Transcription factor MYC2 & 26 & 14 & 9 & 3 & 8 & 9 \\
\hline Salicylic acid & 22 & 15 & 5 & 7 & 3 & 8 \\
\hline Transcription factor TGA & 14 & 9 & 5 & 2 & 1 & 3 \\
\hline Pathogenesis-related protein 1 & 8 & 6 & 0 & 5 & 2 & 5 \\
\hline Ethylene & 37 & 10 & 24 & 2 & 13 & 12 \\
\hline Serine/threonine-protein kinase CTR1 & 25 & 1 & 22 & 0 & 11 & 9 \\
\hline Ethylene-insensitive protein 3 & 3 & 1 & 1 & 1 & 1 & 2 \\
\hline EIN3-binding F-box protein & 9 & 8 & 1 & 1 & 1 & 1 \\
\hline Gibberellin & 33 & 14 & 10 & 8 & 10 & 9 \\
\hline Gibberellin receptor GID1 & 9 & 6 & 2 & 4 & 1 & 4 \\
\hline DELLA protein & 21 & 8 & 6 & 4 & 6 & 3 \\
\hline F-box protein GID2 & 3 & 0 & 2 & 0 & 3 & 2 \\
\hline
\end{tabular}


salt stress at different time point. Plants utilized auxin signaling to modify root development when responding to diverse biotic and abiotic signals including salinity stress [37, 38]. In Arabidopsis, salt stress inhibits the PIN2 (an auxin efflux carriers) expression which is known to dominate gravitropic root response by monitoring bicipital auxin transport [40]. A total of 72 genes required for the auxin signal pathway were differentially expressed under salt treatment in calli. The majority of changed Aquilaria auxin influx carrier and auxin response factor genes were down-regulated under salt stress conditions in calli, however, the genes annotated as auxin-responsive protein (IAA), auxin responsive GH3 gene family and SAUR family protein were both up- and down- regulated during salt treatment (Table 4). In addition, many Aquilaria brassinoteroid signal transduction genes, such as brassinoteroid resistant $1 / 2$ and brassinoteroid insensitive 1-associated receptor kinases (BAK1) family of genes, were also differently expressed under salt stress. In particular, the brassinoteroid resistant $1 / 2$ family genes were down-regulated during salt treatment, however, the BAK1 family members which acting on serine/threonine containing substrate and required for brassinosteroid signal transduction [41], were both up- and down-regulated during salt stress in calli at different time point (Table 4). Furthermore, families of jasmonate ZIM domain-containing protein (JAZ), transcription factor MYC2 and TGA which involved in jasmonic acid and salicylic acid signal transduction [42], respectively, were also different expressed under salt stress in calli, with majority up-regulated. Besides ABA, cytokinine, auxin, brassinoteroid, jasmonic acid and salicylic acid signal pathways in response to salinity stress, other hormones including ethylene and gibberellin also play an important role for salt stress signaling transduction. The comparative analysis of expression profiles indicated that salinity stress induced complex hormone signal pathways.

\section{Salt stress regulated the genes associated with signal transduction: receptor-like kinases, $\mathrm{Ca}^{2+}$-binding proteins and MAPK proteins}

An appropriate defense response to salt stress initially requires recognition of the stress. One of the largest groups of receptor proteins related to the responses to various biotic and abiotic stresses is the receptor-like kinase superfamily which possesses an amino-terminal signal sequence, a transmembrane segment and intracellular serine/threonine kinase domain [43-45]. We identified 688 DEGs annotated as receptor-like kinases induced in the calli under salinity stress (Additional file 8: Table S6, See supporting information). A total of 525 DEGs identified at $24 \mathrm{~h}$ in calli after induced by salt stress were annotated as receptor-like kinases, while a total of 409 DEGs categorized as receptor-like kinases were induced by salt treatment at 120 h. Among these DEGs, 265 were up-regulated and 263 were down-regulated induced by salt treatment after $24 \mathrm{~h}$, whereas, 181 were up-regulated and 230 were downregulated at $120 \mathrm{~h}$ after induced by salt, however, with 279 DEGs co-regulated in $24 \mathrm{~h}$ and $120 \mathrm{~h}$ after induced by salt. Hierarchical clustering of the differentially expressed genes annotated as receptor-like kinases suggested overall difference at control, $24 \mathrm{~h}$ and $120 \mathrm{~h}$ in the calli induced by salinity stress (Fig. 8b).

At least four receptor-like kinase families have been reported to be induced in stress-responsive genes: LRR receptor-like serine/threonine-protein kinase (LRR-RLK), proline-rich receptor-like kinase (PERK), cysteine-rich receptor-like protein kinase (CRR-RLK), and G-type lectin S-receptor-like serine/threonine-protein kinase(SRK) (Additional file 8: Table S6, See supporting information). LRR-RLK family constitutes the largest group among the receptor-like kinases, and regulates various plant processes of plant growth and development underlying the abiotic stress and biotic stress response [44-46]. For instance, FLS2 which is the member of LRR-RLK, recognizes the bacterial flagellin fragment and mediates defense responses in plants [47]. Brassinosteroid insensitive 1-associated receptor kinase (BRI) which is a member of LRR-RLK and is responsible for $\mathrm{BR}$ hormones, regulate plant tolerance to abiotic and biotic stress [46]. Consistent with these, we observed that a total of 262 differential expressed transcripts were annotated as LRR-RLK family members, including 88 of FLS2 subgroup members and 16 of BRI subgroup members (Additional file 8: Table S6, See supporting information). For instance, a FLS2 subfamily member, were induced more than 4 -fold by $\mathrm{NaCl}$ at $24 \mathrm{~h}$ and $120 \mathrm{~h}$ in calli, and we confirmed this by qRT-PCR. PERK family members act as sensors/receptors in cell wall and monitor changes to the cell wall during plant exposure to abiotic and biotic stresses [48]. The first characterized PERK member was Brassica napus PERK1, which expressed in different tissues and rapidly induced by wounding [49]. Another member of PERK family, PERK4, was a positive regulator in $\mathrm{ABA}$ and salt stress reponses. We observed that 92 of transcripts for PERK family members detected were regulated in response to $\mathrm{NaCl}$ treatment and about half of transcripts were up-regulated. However, we observed the majority of the CRR-RLK and SRK family members were up-regulated under salt stress in different time point, as expected for these two families of stress-inducible receptor-like kinases(Additional file 8: Table S6, See supporting information). Many of other $\mathrm{NaCl}$-responsive receptor-like kinases shown in the table are potentially regulators of the $\mathrm{NaCl}$-stress response in A.thaliana. These results suggested that the transcription of the majority of receptor-like genes is controlled and modulated by salt stress, implying their important roles in salt stresses signaling transduction. The downstream events of receptor-like kinase signaling relate to protein 
phosphorylation via a mitogen-activated protein kinase (MAPK, MAPKK, MAPKKK) cascade [50, 51]. In our analysis, salt stress influenced the expression pattern of several mitogen-activated protein kinase genes. A total of 26 differentially expressed transcripts involved in MAPK pathways and up-regulated transcripts were especially predominant in the mitogen-activated protein kinase kinase kinase family (Additional file 8: Table S6, See supporting information). For instance, three mitogen activated protein kinase kinase kinases that encoded MAPKKKA, MAPKKK2 and MAPKKK3 were transcriptionally enriched (Unigene19214_All, Unigene3063_All, CL5738.contig1_All) at $24 \mathrm{~h}$ and $120 \mathrm{~h}$ under salt treatment (Table 5), and we conformed this by qRT-PCR. However, most members of mitogen activated protein kinase kinase and mitogen activated protein kinase genes including the protein encode MPK3 and MEKK2 in A.thaliana that play an important role for stresses response were down-regulated at two time point $[51,52]$ (Table 5). Calcium ions $\left(\mathrm{Ca}^{2+}\right)$ have been demonstrated as a second messenger in plant signaling pathways including response to salt stress. It has been reported that salt treatment trigger a transient increase in $\mathrm{Ca}^{2+}$ level [53]. The activation of MAPK through stresses is always dependent on binding of $\mathrm{Ca}^{2+}$-binding proteins including calmodulins (CaM), calcium-binding protein(CML), calcium-dependent protein kinases (CDPKs) and calcineurin B-like protein $(\mathrm{CBL})$ (Additional file 8: Table S6, See supporting information) [53-56]. In our analysis, 81 differentially expressed unigenes which annotated as $\mathrm{Ca}^{2+}$ dependent proteins were responsive to salt stress signal transduction and up-regulated transcripts were especially predominant in CML proteins at $24 \mathrm{~h}$ and $120 \mathrm{~h}$ under salt stress. Aquilaria calli genes encoding $\mathrm{Ca}^{2}$ + dependent proteins including CaM1, CML37, CML27, CML29 and CDPK1 which are responsible for plant innate immunity [54-56] (Table 5), showed a high expression, suggesting these proteins might be a component of $\mathrm{Ca}^{2+}$ signaling to modulate plant defense response against salt stress. Thus, receptor-like kinases, MAPK cascades and $\mathrm{Ca}^{2+}$ dependent proteins involved in salt stress signal transduction.

\section{Salt stress regulated the expression of transcription factors genes in calli}

Transcription factors are essential for regulation of gene expression, biotic and abiotic stress responses, and signal transduction. The Arabidopsis genome possesses at least 1819 predicted transcription factors that have been classified into 56 families. However, there were 428 predicted transcription factors were regulated by salt treatment. In A.sinensis, a total of 598 DEGs were annotated as transcription factors. 512 DEGs were induced by $150 \mathrm{mM} \mathrm{NaCl}$ at $24 \mathrm{~h}$, with 264 DEGs were upregulated and 248 DEGs were down-regulated, whereas 330 DEGs were induced by $\mathrm{NaCl}$ at 120 h, 128 were upregulated and 202 were down-regulated, however, only 220 DEGs were co-regulated at $24 \mathrm{~h}$ and $120 \mathrm{~h}$ (Additional file 9: Table S7, See supporting information). Hierarchical clustering of DEGs annotated as transcription factors suggested overall difference in control, induced-24 $\mathrm{h}$ and induced-120 h libraries (Fig. 8c). At least seven transcription factor families have been reported to be enriched in stress-responsive genes: AP2/ ERF(Apetala-2/EREBP), MYB(Myeloblastosis), WRKY(named after the wrky amino acid motif), bHLH(basic helix-loop-helix), HOX(Homeodomain-containing transcription factor), NAC(NAC domain protein), and HSF(Heat Shock Factor) (Table 6). AP2/ERF is one of the largest transcription factor family involved in the response to salt stress, which can be further classified into

Table 5 Expression patterns of unigenes annotated as members of MAPK cascades and $\mathrm{Ca}^{2+}$ signal pathways

\begin{tabular}{|c|c|c|c|c|c|}
\hline \multirow[t]{2}{*}{ Gene ID } & \multirow[t]{2}{*}{ Annotation } & \multicolumn{2}{|c|}{ Induced-24 h } & \multicolumn{2}{|c|}{ Induced-120 h } \\
\hline & & $\mathrm{FC}^{*}$ & P-value & FC & P-value \\
\hline Unigene19214_All & Mitogen-activated protein kinase kinase kinase A-like MAPKKKA & 7.06 & 0 & 3.26 & 0 \\
\hline Unigene3063_All & Mitogen-activated protein kinase kinase kinase 2 MAPKKK2 & 8.47 & 0 & 3.64 & $6.27 \mathrm{E}-09$ \\
\hline CL5738.Contig1_All & Mitogen-activated protein kinase kinase kinase 3 MAPKKK3 & 3.07 & $5.38 \mathrm{E}-54$ & 3.13 & $2.58 \mathrm{E}-56$ \\
\hline Unigene21616_All & Mitogen-activated protein kinase kinase 2 MEKK2 & -2.50 & $1.05 \mathrm{E}-130$ & -1.41 & $2.20 \mathrm{E}-59$ \\
\hline CL7087.Contig2_All & Mitogen-activated protein kinase kinase 6 MAPKK6 & -2.06 & $1.68 \mathrm{E}-08$ & -1.67 & $1.56 \mathrm{E}-06$ \\
\hline Unigene2000_All & Mitogen-activated protein kinase 9-like MPK9 & -2.60 & 0 & -1.90 & 2.03E-302 \\
\hline CL9084.Contig2_All & Mitogen-activated protein kinase 3 MPK3 & -2.05 & $7.15 \mathrm{E}-30$ & -2.12 & $3.65 \mathrm{E}-30$ \\
\hline Unigene26936_All & Calmodulin 1 CaM1 & 5.76 & $1.29 \mathrm{E}-60$ & 5.26 & $5.50 \mathrm{E}-41$ \\
\hline Unigene27810_All & Calcium-binding protein CML37 & 4.86 & 0 & 3.36 & $1.08 \mathrm{E}-101$ \\
\hline CL4994.Contig1_All & Calcium-binding protein CML27 & 4.14 & 0 & 3.20 & 0 \\
\hline Unigene11150_All & Calcium-binding protein CML29 & 3.69 & $3.56 \mathrm{E}-42$ & 2.53 & $8.53 \mathrm{E}-14$ \\
\hline Unigene27873_All & Calcium-dependent protein kinase 1 CDPK1 & 2.96 & $1.28-108$ & 3.24 & $1.56 \mathrm{E}-141$ \\
\hline
\end{tabular}

*: Fold change 
Table 6 Transcription factors co-up-regulated by salt stress at different time in A.sinensis calli

\begin{tabular}{|c|c|c|c|c|}
\hline \multirow[t]{2}{*}{ Gene ID } & \multirow[t]{2}{*}{ Annotation } & \multirow[t]{2}{*}{ TF family } & \multicolumn{2}{|l|}{ Log2 ratio } \\
\hline & & & 24 h vs control & $120 \mathrm{~h}$ vs control \\
\hline Unigene18058_All & Ethylene-responsive transcription factor & AP2/ERF & 6.12 & 4.33 \\
\hline Unigene14856_All & Ethylene-responsive transcription factor ERF109-like & AP2/ERF & 4.24 & 2.55 \\
\hline Unigene7108_All & $\begin{array}{l}\text { Ethylene-responsive transcription factor } \\
\text { ERF109 }\end{array}$ & AP2/ERF & 4.18 & 2.50 \\
\hline Unigene4181_All & AP2 domain-containing transcription factor & AP2/ERF & 3.96 & 3.67 \\
\hline Unigene29855_All & AP2 domain class transcription factor & AP2/ERF & 3.91 & 5.33 \\
\hline Unigene21646_All & Ethylene-responsive transcription factor ABR1 & AP2/ERF & 3.06 & 2.40 \\
\hline Unigene18948_All & Ethylene-responsive transcription factor 1B & AP2/ERF & 3.15 & 1.25 \\
\hline CL248.Contig1_All & Ethylene-responsive transcription factor RAP2-7 & AP2/ERF & 2.82 & 1.90 \\
\hline Unigene17032_All & Ethylene-responsive transcription factor 5 & AP2/ERF & 2.35 & 1.51 \\
\hline Unigene6220_All & $\begin{array}{l}\text { dehydration-responsive element binding protein } \\
2 \text { (DREB2) }\end{array}$ & AP2/ERF & 1.98 & 1.72 \\
\hline Unigene381_All & Ethylene-responsive transcription factor ABR1 & AP2/ERF & 1.93 & 2.14 \\
\hline Unigene8092_All & AP2/ERF domain-containing transcription factor & AP2/ERF & 1.84 & 1.95 \\
\hline Unigene20214_All & ethylene-responsive element binding protein 1 & AP2/ERF & 1.66 & 1.25 \\
\hline Unigene14338_All & AP2/EREBP transcription factor & AP2/ERF & 1.47 & 1.46 \\
\hline Unigene25279_All & AP2/ERF domain-containing transcription factor & AP2/ERF & 1.40 & 1.90 \\
\hline Unigene9921_All & MYB superfamily protein 1 & MYB & 5.95 & 4.32 \\
\hline Unigene11776_All & Transcription factor MYB75 & MYB & 5.73 & 3.60 \\
\hline Unigene14868_All & Transcription factor MYB39 & MYB & 5.43 & 3.08 \\
\hline Unigene26918_All & Putative MYB family transcription factor & MYB & 5.27 & 3.86 \\
\hline CL3573.Contig1_All & MYB-related protein MYB4 & MYB & 5.25 & 4.09 \\
\hline Unigene28480_All & MYB-related protein 78 & MYB & 5.09 & 2.99 \\
\hline Unigene13545_All & Putative MYB family transcription factor & MYB & 4.96 & 2.16 \\
\hline CL5989.Contig1_All & Transcription factor MYB21 & MYB & 4.71 & 2.93 \\
\hline Unigene5251_All & MYB-related protein & MYB & 4.14 & 3.10 \\
\hline CL5340.Contig1_All & $\begin{array}{l}\text { Putative MYB family } \\
\text { transcription factor }\end{array}$ & MYB & 3.81 & 2.79 \\
\hline CL4273.Contig2_All & MYB-related protein & MYB & 2.92 & 3.11 \\
\hline CL277.Contig1_All & MYB superfamily proteins & MYB & 2.08 & 4.09 \\
\hline Unigene23227_All & myb-related protein & MYB & 2.74 & 1.95 \\
\hline Unigene10979_All & Transcription factor MYB21 & MYB & 2.37 & 1.24 \\
\hline Unigene5227_All & $\begin{array}{l}\text { myb-related protein } \\
306 \text {-like }\end{array}$ & MYB & 1.78 & 1.21 \\
\hline CL8451.Contig1_All & $\begin{array}{l}\text { MYB transcription } \\
\text { factor R3 type }\end{array}$ & MYB & 1.58 & 1.33 \\
\hline Unigene38347_All & $\begin{array}{l}\text { WRKY transcription } \\
\text { factor } 22 \text {-like }\end{array}$ & WRKY & 4.79 & 3.01 \\
\hline CL9188.Contig2_All & $\begin{array}{l}\text { WRKY29-1 } \\
\text { transcription factor }\end{array}$ & WRKY & 4.75 & 3.66 \\
\hline Unigene2832_All & $\begin{array}{l}\text { Transcription factor } \\
\text { WRKY40 }\end{array}$ & WRKY & 4.56 & 4.60 \\
\hline Unigene29386_All & $\begin{array}{l}\text { WRKY transcription } \\
\text { factor } 28\end{array}$ & WRKY & 3.57 & 2.40 \\
\hline Unigene27408_All & WRKY transcription factor 23 & WRKY & 3.07 & 1.46 \\
\hline Unigene1977_All & WRKY transcription factor 15 & WRKY & 2.85 & 1.82 \\
\hline
\end{tabular}


Table 6 Transcription factors co-up-regulated by salt stress at different time in A.sinensis calli (Continued)

\begin{tabular}{|c|c|c|c|c|}
\hline Unigene26943_All & WRKY transcription factor 23 & WRKY & 2.82 & 1.94 \\
\hline Unigene4489_All & WRKY transcription factor 47 & WRKY & 2.58 & 3.19 \\
\hline CL1269.Contig1_All & WRKY transcription factor 33 & WRKY & 2.38 & 2.26 \\
\hline Unigene7236_All & WRKY transcription factor 75 & WRKY & 2.20 & 4.03 \\
\hline Unigene23162_All & Probable WRKY transcription factor 14 & WRKY & 1.99 & 1.88 \\
\hline Unigene27807_All & WRKY transcription factor & WRKY & 1.88 & 2.40 \\
\hline Unigene20429_All & WRKY transcription factor 17 & WRKY & 1.82 & 1.18 \\
\hline Unigene15555_All & WRKY transcription factor 6 & WRKY & 1.63 & 1.89 \\
\hline Unigene25162_All & WRKY transcription factor 11 & WRKY & 1.60 & 1.28 \\
\hline Unigene11168_All & WRKY transcription factor 65 & WRKY & 1.28 & 1.77 \\
\hline Unigene14452_All & WRKY transcription factor 28 & WRKY & 1.26 & 1.22 \\
\hline CL8216.Contig1_All & Transcription factor bHLH122 & bHLH & 2.49 & 1.28 \\
\hline CL1535.Contig1_All & transcription factor bHLH123 & bHLH & 1.79 & 1.14 \\
\hline Unigene29356_All & transcription factor bHLH30-like & $\mathrm{bHLH}$ & 1.75 & 1.80 \\
\hline Unigene19013_All & Transcription factor bHLH130 & bHLH & 1.43 & 1.39 \\
\hline Unigene25168_All & Homeobox-leucine zipper protein HOX11 & $\mathrm{HOX}$ & 6.31 & 5.99 \\
\hline Unigene11236_All & homeobox-leucine zipper protein HOX6-like & $\mathrm{HOX}$ & 4.89 & 1.89 \\
\hline Unigene15687_All & Homeobox-leucine zipper protein HOX27 & $\mathrm{HOX}$ & 1.85 & 1.51 \\
\hline Unigene35957_All & homeobox-leucine zipper protein HAT14-like & $\mathrm{HOX}$ & 1.74 & 1.71 \\
\hline Unigene27798_All & NAC domain protein NAC4 & NAC & 6.41 & 4.04 \\
\hline Unigene24899_All & NAC transcription factor NAM-2 & NAC & 4.51 & 1.86 \\
\hline CL6345.Contig1_All & NAC domain-containing protein 68 & NAC & 2.00 & 1.35 \\
\hline Unigene14392_All & NAC domain-containing protein 18 & NAC & 1.88 & 1.37 \\
\hline Unigene26036_All & NAC domain protein NAC2 & NAC & 1.39 & 1.17 \\
\hline CL598.Contig8_All & Heat stress transcription factor & HSF & 4.92 & 5.77 \\
\hline Unigene13160_All & heat stress transcription factor $\mathrm{A}-4 \mathrm{a}$ & HSF & 2.20 & 1.45 \\
\hline CL2103.Contig2_All & Heat stress transcription factor B-2a & HSF & 1.95 & 1.25 \\
\hline Unigene10292_All & $\begin{array}{l}\text { Heat stress transcription factor } \\
\text { B-2a-like }\end{array}$ & HSF & 1.59 & 1.10 \\
\hline
\end{tabular}

four subfamilies: ERF, DREB, AP2, RAV [57]. Of these, $E R F s$ and AP2s expression levels were found to be correlated with salt tolerance and activate the downstream salt-responsive genes. In A.sinensis, we observed 73 of AP2/ERF family transcripts were regulated by salt stress (Additional file 9: Table S7, See supporting information), and the up-regulated transcripts were detected in three AP2/ERF family's subgroups(AP2, ERF, DREB) at two time point (Table 6). However, the ERF subfamily members were found to be significantly induced by salt stress at $24 \mathrm{~h}$ and $120 \mathrm{~h}$ in A.sinensis calli (Table 6). Recent analysis of the MYB family members expression level concluded that most of MYB-transcription factor are responsible for stresses and hormones [58]. Consistent with this analysis, in Arabidopsis, at least one third of the 84 predicted MYB transcription factors were enriched by $\mathrm{NaCl}$ at the transcript abundance level, and in wheat 16 of 60 detectable MYB family members were induced by high salt at transcript level $[32,59]$. Similarly, we observed that a total of 71 DEGs were annotated as MYB family members and 14 of 24 co-regulated transcripts were enriched by $\mathrm{NaCl}$ (Additional file 9: Table S7, See supporting information). MYB1(Unigene9921_All) and MYB4(CL3573.Contig1_All), were induced more than 4 -fold by $\mathrm{NaCl}$ at each of two time point (Table 6), and we confirmed this by qRT-PCR. In addition, the other MYB family members such as MYB75, MYB39, MYB78 and MYB21 were up-regulated by $\mathrm{NaCl}$. The majority of WRKY family members which contain zinc-finger motifs are known to involve in biotic and abiotic response [60]. In Arabidopsis, more than 1/2 WRKY transcription factors were induced by $\mathrm{NaCl}$, and the members of WRKY17, WRKY25 and WRKY33 were significantly enriched [32]. We observed that 58 DEGs were annotated as WRKY family transcription factors and the majority of the WRKY family members were up-regulated by salt treatment at $24 \mathrm{~h}$ and $120 \mathrm{~h}$ (Additional file 9: Table S7, See 
supporting information). We also used qRT-PCR to confirm these observations for WRKY29, WRKY40 and WRKY75 (Table 6), which were significantly enriched by salt stress. Three other large families of transcription factors with distinct DNA binding motifs are bHLH, HOX and $\mathrm{NAC}$ genes [32]. All of these families contained $\mathrm{NaCl}-$ responsive genes, however, the members of $\mathrm{HOX}$ and NAC families were remarkably enriched in $\mathrm{NaCl}$-induced transcripts. Furthermore, most of the HSF family members were enriched by salt stress [61] (Table 6), as expected for this family of stress-responsive transcription factors. Many other transcription families including MYC, GRAS, TGA, TCP and GATA (Additional file 9: Table S7, See supporting information), contained $\mathrm{NaCl}$-responsive genes and played important role for the physiological response to $\mathrm{NaCl}$ treatment. The large number of up- or down-regulated transcription factor genes we observed, is consistent with the existence of a complex signal transduction network underlying the response to salt stress.

\section{Putative genes involved in biosynthesis of 2-(2- phenylethyl)chromones in calli under salinity stress} Our study showed that salinity stress induced the production of 2-(2-phenylethyl)chromones in A.sinensis calli. These results suggested that the activities of enzymes which are responsible for biosynthesis of 2-(2-phenylethyl)chromones were enriched by salinity stress. The RNA-seq analysis indicated that the diarylheptanoid and ginerol biosynthesis pathways were significantly enriched, however, curcumin synthase which is a plant polyketide synthase and is the most important synthase for diarylheptanoid and ginerol biosynthesis [62], could not be annotated the three libraries including control, induced- $24 \mathrm{~h}$ and induced$120 \mathrm{~h}$. According to the structure of 2-(2-phenylethyl)chromones, we proposed that the biosynthesis of 2-(2-phenylethyl)chromones might be similar to diarylheptanoids, and polyketide synthases (PKSs) except curcumin synthase may play a vital role in the biosynthesis of 2-(2-phenylethyl)chromones [63]. The transcriptome data indicated that the expression of chalcone synthase which is a member of type III polyketide synthase was affected after induced by salt for $24 \mathrm{~h}$ and $120 \mathrm{~h}$ (Additional file 10: Table S8, See supporting information). Among these genes, the chalcone synthase 1 (CHS1) was up-regulated in calli after induced for $24 \mathrm{~h}$ and $120 \mathrm{~h}$; however, the expression of CHS2 was reduced at $120 \mathrm{~h}$ (Table 7). The phylogenetic tree was constructed according to the PKSs amino acid sequences by Neighbor-Joining method using MEGA 6.0 software to investigate the evolutionary relationship and distribution among PKSs from different species. The phylogenetic tree analysis allow the classification of PKSs in higher plants in two different clusters called CHS(chalcone-prodcuing)and non-CHS (nonchalcone-producing) cluster, and AsCHS1 was grouped in non-CHS cluster,
Table 7 Expression patterns of genes involved in biosynthesis of 2-(2-phenylethyl)chromones

\begin{tabular}{|c|c|c|c|c|c|}
\hline \multirow[t]{2}{*}{ Gene ID } & \multirow[t]{2}{*}{ Annotation } & \multicolumn{2}{|c|}{ Induced-24 h } & \multicolumn{2}{|c|}{ Induced-120 h } \\
\hline & & $\mathrm{FC}^{*}$ & P-value & FC & P-value \\
\hline CL6258.Contig1_All & $\begin{array}{l}\text { Chalcone synthase } \\
\text { (CHS1) }\end{array}$ & 4.43 & 0 & 2.23 & $6.31 \mathrm{E}-72$ \\
\hline Unigene9694_All & $\begin{array}{l}\text { Chalcone synthase } \\
\text { (CHS2) }\end{array}$ & - & - & -1.86 & 0 \\
\hline CL6576.Contig1_All & $\begin{array}{l}\text { Flavonol -O- } \\
\text { methyltransferase- } \\
\text { like protein } \\
\text { (OMT1) }\end{array}$ & 5.04 & 0 & 4.39 & 0 \\
\hline Unigene30708_All & $\begin{array}{l}\text { Flavonol -O- } \\
\text { methyltransferase } \\
3\end{array}$ & 4.65 & 2.41E-94 & 3.12 & $8.68 \mathrm{E}-25$ \\
\hline Unigene11142_All & $\begin{array}{l}\text { Caffeoyl-CoA-O- } \\
\text { methyltransferase }\end{array}$ & 3.43 & 0 & 2.47 & 0 \\
\hline
\end{tabular}

*: Fold change

including curcuminoid synthase (CUS) from monocots Oriza sativa, diketide-CoA synthase (DCS) and curcumin synthase (CURS) from monocots Curcuma longa, and AsCHS2 was grouped in CHS cluster [63] (Additional file 11: Figure S3). These results suggested that AsCHS1 might possess an unusual catalytic potential and could be the important enzyme for biosynthesis of 2-(2-phenylethyl)chromones. 2-(2-phenylethyl)chromones always display $\mathrm{O}$ methyl groups on the phenylethylchromone scaffold. It suggested that $O$-methyltransferase plays a critical role in transferring $O$-methyl groups to 2-(2-phenylethyl)chromone scaffolds. Recently, transcriptome analysis result from the medical plant Glaucium flavum indicated that the $O$-methyltransferase (OMTs) were required for benzylisoquinoline alkaloid (which displays four O-methyl groups at C6, C7, C3'and C4' on the benzylisoquinoline scaffold) biosynthesis [64]. Transcriptome resource analysis of Aquilaria calli revealed the biosynthesis of 2-(2phenylethyl)chromones required the members of flavonol 3-O-methyltransferase and caffeoyl-CoA O-methyltransferase families transfer $O$-methyl groups to the 2-(2-phenylethyl)chromones scaffolds (Table 7). RNA-seq analysis showed that a total of 21 DEGs were annotated as flavonol 3-O-methyltransferase and a total of 8 DEGs were annotated as caffeoyl-CoA $O$-methyltransferase (Additional file 10: Table S8, See supporting information). More than half of transcripts annotated as $\mathrm{O}$-methyltransferase were enriched by salinity stress at $24 \mathrm{~h}$ and $120 \mathrm{~h}$. These results demonstrated that chalcone synthase and $O$ methyltransferase play a critical role in biosynthesis of 2-(2-phenylethyl)chromones.

\section{Conclusions}

We firstly identified 41 2-(2-phenylethyl)chromones from the salt-treated A.sinensis calli by LC-MS system. To find 
the transcripts responsible salinity stress, a comprehensive transcriptome analysis was conducted from the control calli and induced calli with $150 \mathrm{mM} \mathrm{NaCl}$ treatment. A total of 93041 unigenes with an average length of $1562 \mathrm{nt}$ were obtained, and they were annotated by comparing them with the public database including NR, Swiss-Prot, KEGG, COG and GO database. Our transcriptional analysis revealed numerous genes that were differentially expressed at $24 \mathrm{~h}$ and $120 \mathrm{~h}$ under salt stress in calli. The differentially expressed candidate genes from RNA-seq were confirmed by qRT-PCR analysis. We found that numerous genes involved in hormone signal transduction, MAPK cascades signal transduction, $\mathrm{Ca}^{2+}$ signal transduction, or encoding receptor-like kinase and transcription factors showed different expressions between the control and salt-treated calli. These differences suggested that a complex signal pathway were induced in response to salinity stress. In addition, our RNA-seq analysis observed that chalcone synthase and $O$-methyltransferase may regulate the biosynthesis of 2-(2-phenylethyl)chromones. These results provide a better understanding of salt stresses signal transduction in A.sinensis calli, and clues to facilitate the mechanism of agarwood formation.

\section{Methods}

\section{Plant material and chemical treatment}

The A.sinensis leaves(Zhongshan, Guangdong province, China) were cut into $1 \mathrm{~cm}$ diameter, surface-sterilized by Clorox (2.5\%) for $10 \mathrm{~min}$, disinfected using $70 \%$ ethanol for $30 \mathrm{~s}$, and washed with sterile distilled water for 4 times. The treated leaves pieces were plated on the MS medium with $2 \mu \mathrm{g} / \mathrm{mL}$ naphthalene-1-acetic acid (NAA) and $1 \mu \mathrm{g} / \mathrm{mL}$ 6-benzylaminopurine (6-BA) for inducing callus. After incubation at $25{ }^{\circ} \mathrm{C}$ for one month in dark, callus were sub-cultured onto the fresh MS medium containing $2 \mu \mathrm{g} / \mathrm{mL}$ NAA, $1 \mu \mathrm{g} / \mathrm{mL}$ 6-BA, $1 \mu \mathrm{g} / \mathrm{mL}$ dichlorophenoxyacetic acid (2,4-D) and $1 \mu \mathrm{g} / \mathrm{mg}$ kinetin(KT) every month. To identify and speculate 2-(2-phenylethyl)chromones, the calli were transferred to the medium containing $150 \mathrm{mM} \mathrm{NaCl}$ and harvested every 4 weeks for analysis by LCMS-IT-TOF. To optimize the sequencing timing, $150 \mathrm{mM} \mathrm{NaCl}$ treated calli were harvested at $0 \mathrm{~h}$, $24 \mathrm{~h}, 72 \mathrm{~h}, 120 \mathrm{~h}, 168 \mathrm{~h}$, and $216 \mathrm{~h}$. For salt treatment, $\mathrm{NaCl}$ was added to the medium with a final concentration of $75 \mathrm{mM}, 150 \mathrm{mM}$, and $300 \mathrm{mM}$. The calli subcultured for 4 weeks after inoculation were transferred onto these medium with or without $\mathrm{NaCl}$, and were harvested at 10 days. Following salt treatment, the calli were collected and washed for 5 min by distilled water.

\section{Analysis of 2-(2-phenylethyl)chromones of treated Aquilaria calli}

The calli were dried at $65{ }^{\circ} \mathrm{C}$ and extracted with $95 \%$ methanol (0.1 g dried calli with $1 \mathrm{~mL} 95 \%$ methanol) at room temperature in an ultrasonic bath for half an hour. The extracts were then centrifuged at $12000 \mathrm{rpm}$ for one hour at $4{ }^{\circ} \mathrm{C}$ and the supernatant were analyzed with LCDAD-IT-TOF-MS system (Shimadzu, Kyoto, Japan). For liquid Chromatography analysis, Chromatographic separations were carried out on an Agilent SB- $\mathrm{C}_{18}$ column $(250 \times 4.6 \mathrm{~mm}$ i.d., particle size $5 \mu \mathrm{m}$, Agilent Technologies. Palo Alto, CA, USA). The injection volume was set at $10 \mu \mathrm{L}$. The mobile phase was composed of acetonitrile (A) and $0.1 \%$ aqueous formic acid (B), and delivered at $1.0 \mathrm{~mL} / \mathrm{min}$ following the gradient program: $0-20 \mathrm{~min}$, $10 \%-20 \%$ A; $20-35 \min , 20 \%-25 \%$ A; $35-55$ min, $25 \%-35 \%$ A; $55-70$ min, $35 \%-38 \%$ A; $70-90$ min, $38 \%-50 \% \mathrm{~A} ; 90-105 \mathrm{~min}, 50-70 \% \mathrm{~A} ; 105-$ $120 \mathrm{~min}$, isocratic $70 \% \mathrm{~A} ; 120-130 \mathrm{~min}, 70 \%-90 \% \mathrm{~A}$. UV absorption over 190-400 $\mathrm{nm}$ was recorded by DAD module. In mass spectrometer domain, an hybrid ion trap-time-of-flight mass spectrometer (IT-TOF-MS, Shimadzu) equipped with an electrospray ionization (ESI) interface was connected to LC system via a PEEK tube (0.13 $\mathrm{mm}$ i.d.) to perform high-resolution tandem mass spectrometry. The accurate ion axis was calibrated using the sodium trifluoroacetate (TFA) clusters as reference. Positive mass spectra were recorded in the full scan and automatic multiple stage fragmentation scan modes over a range of $m / z 100-1000$ for all MS1, MS2 spectra acquisition. The accuracy of the assigned chemical formula was determined using mass difference tolerance of $\pm 5 \mathrm{ppm}$, which was calculated by the deviation between the experimental mass and calculated mass.

\section{RNA extraction and CDNA library preparation}

Total RNA was extracted from the control and $\mathrm{NaCl}$ induced calli at $24 \mathrm{~h}, 120 \mathrm{~h}$, using the total RNA extraction kit (Norgen, Cat 72200) according to the manufacturer's recommendations. The RNA concentration and integrity were analyzed by Nanodrop2000 (ND-100 Spectrophotometer, Peqlab). The RNA from the induced calli (three replicates) was mixed in equal proportion to generate the pool for the induced library, and the RNA from the control callus (three replicates from control calli at $24 \mathrm{~h}$ and three replicates from control calli at $120 \mathrm{~h}$ ) was mixed to a pool for the control library.

\section{Library construction and De novo transcriptome sequencing}

Total RNA from control and induced calli was purified using oligo(dT) magnetic beads and fragmented into small pieces according to the manufacturer's instruction (Illumina, San Diego, CA USA). The cleaved fragments were then used to synthesize first-strand cDNA with random hexamer primiers and reverse transcriptase (Invitrogen, Carlsbad, CA USA). Second-strand cDNA was synthesized using DNA polymerase I (Invitrogen, 
Carlsbad, CA USA), dNTPs and RNase H. Following, the cDNA fragment were amplified by PCR and purified after removal of the ligation adaptors and end-repair to construct the final library. Three libraries with the insert size ranging from 150 to $250 \mathrm{bp}$ were sequenced on the Illumina HiSeq-2000 platform using the 100 bp paired-end approach. In total, 74,881,134, 80,382,270 and 77,355,892 raw reads were generated by Solexa/Illumina sequencing in three libraries respectively, which had been deposited in Sequence Read Archive database in NCBI, Accession No. SRA319923.

\section{De novo Transcriptome Assembly and Annotation of Unigene Functions}

After removal of the adaptor sequences, reads in low quality (more than $20 \%$ of reads having quality value $\leq 10$ ) and reads with unknown nucleotides larger than $5 \%$, the clean reads assembly was carried out with short reads assembling program- Trinity program [65]. Firstly, Trinity assembled the reads with a certain length of overlap into contigs, clustered contigs into clusters and constructed de Brujin graphs for each cluster which represented the full transcriptional complexity for a given gene, and then partitioned the full read set among these graphs. Finally, Trinity processed the individual graphs, traced the paths that the reads took within the graph, ultimately programed full-length transcripts, and tested apart transcripts that corresponded to paralogous genes. The final sequences assembled by trinity were defined as 'unigenes'. The Trinity unigenes of three libraries were further assembled with TGICL software to get non-redundant unigenes for further analysis[66]. The functions of the unigenes were aligned using BLASTX searches (with an E-value threshold of $10^{-5}$ ) to the public protein database including the NCBI nonredundant database (NR) (http://www.ncbi.nlm.nih.gov), the Swiss-Pot database (http://www.expasy.ch/spot), Cluster of Orthologous Groups(COG) database (http://www.nc bi.nlm.gov/COG), and Kyoto Encyclopedia of Genes and Genomes (KEGG) database (http://www.geno me.jp/kegg). The proteins with highest sequence similarity were retrieved to analysis. COG matched each annotated sequence to an ancient conserved domain to predict and classify possible functions, while KEGG produced the inner-cell metabolic pathways. Based on NR annotation, GO functional annotation and further functional classification were carried out with Blast2GO program (http://www.blast2go.com/b2ghome) [67].

\section{Functional Analysis of differentially expressed genes}

The unigenes expressed value and transcript levels were calculated by FPKM method [68]. The rigorous algorithm which described by Stephane Audic was used to identify differentially expressed genes between different samples [69], and False discovery rare(FDR) method was applied to analyze the threshold of the P-value in multiple test. We choose "FDR $\leq 0.001$ and the absolute value of $\log 2 \mathrm{Ra}$ tio $\geq 1$ " as the threshold to identify the significance of gene expression difference. All differentially expressed genes were performed to $\mathrm{GO}$ enrichment analysis, and were mapped to KEGG database to identify significantly enrich metabolic pathways or signal transduction pathways.

\section{Quantitative real-time PCR (qRT-PCR) analysis}

To investigate the mRNA expression of putative genes involved in phenylethyl chromones biosynthesis and salt stress, qRT-PCR was performed using the Bio-Rad Realtime System and SYBR Green PCR Master kit according to the manufacturer's instruction. Total RNA from different samples was reverse transcribed using the MLV kit (Sigma) according the manufacturer's recommendations. $10 \mathrm{ng}$ template cDNA was used in $20 \mu \mathrm{L}$ PCR reaction mixture containing $10 \mu \mathrm{L}$ fast SYBR Green master mix (Invitrogen) and $0.2 \mu \mathrm{M}$ gene-specific primer (Additional file 7: Table S5; See supporting information). A DNA Engine Option 2 thermal cycler was carried out as the following program: one cycle of $95{ }^{\circ} \mathrm{C}$ for $3 \mathrm{~min}$ and 40 cycles of $95^{\circ} \mathrm{C}$ for $30 \mathrm{~s}$ and $60^{\circ} \mathrm{C}$ for $30 \mathrm{~s}$. The expression of candidate genes was normalized to the Actin gene which was normally used as an internal control [4]. The relative gene expression level was normalized by rasing 2 to the power of the negative value of $\Delta \Delta \mathrm{Ct}$ for each sample [70]. For all the qRT-PCR analysis, three biological experiments and three experimental replicates were calculated to analyze the candidate gene expression.

\section{Additional files}

Additional file 1: Table S1. The length distribution of unigenes. (DOCX 18 kb)

Additional file 2: Figure S1. Gene ontology (GO) functional enrichment analysis of assembled unigenes. A total of 53514 matched unigenes were classfied into three principal categories: biological process, cellular component and molecular function. (PPTX 165 kb)

Additional file 3: Figure S2. COG functional classification of all unigenes sequence. 29 387(31.59\%) transcripts showed significant similarity to sequences in the COG databases and were clustered into 25 categories. (PPTX $213 \mathrm{~kb}$ )

Additional file 4: Table S2. The KEGG analysis of all unigenes. (XLSX $17 \mathrm{~kb}$ )

Additional file 5: Table S3. The KEGG analysis of differentially expressed genes at $24 \mathrm{~h}$ in salt-treated calli. (XLSX $20 \mathrm{~kb}$ )

Additional file 6: Table S4. The KEGG analysis of differentially expressed genes at $120 \mathrm{~h}$ in salt-treated calli. (XLSX 19 kb)

Additional file 7: Table S5. The specific primers of 26 candidate genes. (XLSX $15 \mathrm{~kb}$ )

Additional file 8: Table S6. The number of differentially expression genes related to receptor kinase, MAPK pathway and $\mathrm{Ca}^{2+}$ signal pathway. (DOCX $22 \mathrm{~kb}$ )

Additional file 9: Table S7. The number of differentially expressed genes related to transcription factors. (DOCX 20 kb) 
Additional file 10: Table S8. The number of differentially expressed ungenes involved in biosynthesis of 2-(2-phenylethyl)chromones. (DOCX $19 \mathrm{~kb})$

Additional file 11: Figure S3 Phylogenetic tree analysis of plant type III PKSs. The tree was constructed by neighbor-joining algorithm and the reliability of the tree was measured by bootstrap analysis with 1000 replicates. The indicated scale represents 0.05 amino acid substitutions per site. (PPTX $150 \mathrm{~kb}$ )

\section{Abbreviations}

BLAST: Basic Local Aligment Search Tool; CBF: CRT binding transcription factor; CHS: chalcone synthase; COG: clusters of orthologous groups of proteins; DEGs: differentially expression genes; FDR: false discovery rate; Go: gene ontology; KEGG: The KEGG resource for deciphering the genome; Nr: ncbi nr database; qPCR: quantitative real-time PCR; RNA-seq: RNA sequencing; TF: transcription factor.

\section{Acknowledgements}

We would like to thank the Beijing Genomic Institute for the Illumina sequencing of Aquilaria sinensis calli.

\section{Funding}

This work was supported by the Beijing Natural Science Foundation (No.7154216), the National Natural Science Foundation of China (No. 81503262) and the Doctoral Foundation of Baotou Medical College(No. BSJJ201607).

\section{Availability of data and materials}

Not applicable.

\section{Authors' contributions}

XHW carried out differential gene expression analysis, qRT-PCR and drafted the manuscript. BWG identified and speculated 2-(2-phenylethyl)chromones from salt-treated A.sinensis calli, and performed statistical analysis and visualization of results. XL, ZXZ and HYF provided the suggestion for editing and revising the manuscript. XJD, ZL and WJ participated in RNA-Seq analysis. Shepo Shi and Pengfei Tu initiated the project and supervised the work throughout. All authors read and approved the final manuscript.

\section{Competing interests}

The authors declare that they have no competing interests.

\section{Consent to publish}

Not applicable.

\section{Ethic}

Not applicable.

\section{Author details}

'Modern Research Center for Traditional Chinese Medicine, Beijing University of Chinese Medicine, Beijing 100029, China. ${ }^{2}$ Baotou Medical College, Baotou 014060, China. ${ }^{3}$ College of Pharmacy, Zhejiang Chinese Medical University, Hangzhou 310053, China.

\section{Received: 7 April 2016 Accepted: 13 May 2016}

Published online: 26 May 2016

\section{References}

1. Naef R. The volatile and semi-volatile constituents of agarwood, the infected heartwood of Aquilaria species: A review. Flavour Frag J. 2011:26(2):73-89.

2. Xu Y, Zhang Z, Wang M, Wei J, Chen H, Gao Z, Sui C, Luo H, Zhang X, Yang $Y$, et al. Identification of genes related to agarwood formation: transcriptome analysis of healthy and wounded tissues of Aquilaria sinensis. BMC Genomics. 2013;14:227-43.

3. Zhang XL, Liu YY, Wei JH, Yang Y, Zhang Z, Huang JQ, Chen HQ, Liu YJ. Production of high-quality agarwood in Aquilaria sinensis trees via wholetree agarwood-induction technology. Chinese Chem Lett. 2012;23(6):727-30.
4. Gao ZH, Wei JH, Yang Y, Zhang Z, Zhao WT. Selection and validation of reference genes for studying stress-related agarwood formation of Aquilaria sinensis. Plant Cell Rep. 2012;31(9):1759-68.

5. China pharmacopoeia Committee. The Pharmacopoeia of People's Republic of China(I). Beijing: Chemical Industry Press; 2010.

6. Chen HQ, Wei JH, Yang JS, Zhang Z, Yang Y, Gao ZH, Sui C, Gong B. Chemical constituents of agarwood originating from the endemic genus Aquilaria plants. Chem Biodivers. 2012;9(2):236-50.

7. Chen D, Xu ZR, Chai XY, Zeng KW, Jia YX, Bi D, Ma ZZ, Tu PF. Nine 2-(2phenylethyl)chromone derivatives from the resinous wood of Aquilaria sinensis and their inhibition of LPS-induced NO production in RAW 264.7 cells. Eur J Org Chem. 2012;27:5389-97.

8. Ishihara M, Tsuneya T, Uneyama K. Fragrant sesquiterpenes from agarwood. Phytochemistry. 1993;33(5):1147-55.

9. Kumeta Y, Ito M. Characterization of $\delta$-guaiene synthases from cultured cells of Aquilaria, responsible for the formation of the sesquiterpenes in agarwood. Plant Physiol. 2010;154(4):1998-2007.

10. Ibrahim SRM, GAM. Natural occurring 2-(2-phenylethyl) chromones, structure elucidation and biological activities. Nat Prod Res. 2015;29(16):1-32.

11. Yoon JS, Lee MK, Sung SH, Kim YC. Neuroprotective 2-(2phenylethyl)chromones of Imperata cylindrica. J Nat Prod. 2006;69(2):290-1.

12. Liu J, Wu J, Zhao YX, Deng YY, Mei WL, Dai HF. A new cytotoxic 2-(2-phenylethyl)chromone from Chinese eaglewood. Chinese Chem Lett. 2008;19(8):934-6.

13. Yang DL, Wang H, Guo ZK, Dong WH, Mei WL, Dai HF. A new 2-(2-phenylethyl)chromone derivative in Chinese agarwood 'Qi-Nan' from Aquilaria sinensis. J Asian Nat Prod Res. 2014;16(7):770-6.

14. Li W, Cai CH, Dong WH, Guo ZK, Wang H, Mei WL, Dai HF. 2-(2Phenylethyl)chromone derivatives from Chinese agarwood induced by artificial holing. Fitoterapia. 2014;98:117-23.

15. Qi SY, He ML, Lin LD, Zhang $C H$, Hu LJ, Zhang HZ. Production of 2-(2-phenylethyl)chromones in cell suspension cultures of Aquilaria sinensis. Plant Cell Tiss Org. 2005;83(2):217-21.

16. Okudera Y, Ito M. Production of agarwood fragrant constituents in Aquilaria calli and cell suspension cultures. Plant Biotechnol. 2009;26(3):307-15.

17. Zhu JK. Salt and drought stress signal transduction in plants. Annu Rev Plant Biol. 2002;53:247-73.

18. Kempa S, Krasensky J, Dal Santo S, Kopka J, Jonak C. A central role of abscisic acid in stress-regulated carbohydrate metabolism. PLoS One. 2008;3(12):e3935.

19. He T, Cramer GR. Abscisic acid concentrations are correlated with leaf area reductions in two salt-stressed rapid-cycling Brassica species. Plant Soil. 1996;179(1):25-33.

20. Cramer GR, Quarrie SA. Abscisic acid is correlated with the leaf growth inhibition of four genotypes of maize differing in their response to salinity. Func Plant Biol. 2002;29(1):111-5.

21. Popova LP, Stoinova ZG, Maslenkova LT. Involvement of abscisic acid in photosynthetic process in Hordeum vulgare L. during salinity stress. J Plant Growth Regul. 1995;14(4):211-8.

22. Fragnire C, Serrano M, Abou-Mansour E, Métraux JP, Haridon FL. Salicylic acid and its location in response to biotic and abiotic stress. FEBS Lett. 2011;585(12):1847-52.

23. Clause SD, Sasse JM. Brassinosteroids: essential regulators of plant growth and development. Annu Rev Plant Biol. 1998:49:427-51.

24. Chinnusamy V, Schumaker K, Zhu JK. Molecular genetic perspectives on cross-talk and specificity in abiotic stress signalling in plants. J Exp Bot. 2004;55(395):225-36.

25. Huang GT, Ma SL, Bai LP, Zhang L, Ma H, Jia P, et al. Signal transduction during cold, salt, and drought stresses in plants. Mol Biol Rep. 2012;39(2):969-87.

26. Luo JL, Tang SH, Peng XJ, Yan XH, Zeng XH, Li J, Li XF, Wu G. Elucidation of cross-talk and specificity of early response mechanisms to salt and PEG-simulated drought stresses in Brassica napus using comparative proteomic analysis. PLoS One. 2015;10(10):e0138974.

27. Gupta B, Huang B. Mechanism of salinity tolerance in plants: physiological, biochemical, and molecular characterization. Int J Genomics. 2014;2014:701596

28. Johnson RR, Wagner RL, Verhey SD, Walker-Simmons MK. The abscisic acid-responsive kinase PKABA1 interacts with a seed-specific abscisic acid response element-binding factor, TaABF, and phosphorylates TaABF peptide sequences. Plant Physiol. 2002;130(2):837-46. 
29. Hu Y, Chen L, Wang H, Zhang L, Wang F, Yu D. Arabidopsis transcription factor WRKY8 functions antagonistically with its interacting partner VQ9 to modulate salinity stress tolerance. Plant J. 2013;74:730-45.

30. Mizoi J, Shinozaki K, Yamaguchi-Shinozaki K. AP2/ERF family transcription factors in plant abiotic stress responses. Biochim Biophys Acta. 2012;1819(2):86-96.

31. Song SY, Chen Y, Chen J, Dai XY, Zhang WH. Physiological mechanisms underlying OsNAC5-dependent tolerance of rice plants to abiotic stress. Planta. 2011;234(2):331-45.

32. Jiang $Y$, Deyholos MK. Comprehensive transcriptional profiling of $\mathrm{NaCl}$-stressed Arabidopsis roots reveals novel classes of responsive genes. BMC Plant Biol. 2006;6:25.

33. Wang $Y$, Tao $X$, Tang XM, Xiao L, Sun JL, Yan XF, Li D, Deng HY, Ma XR. Comparative transcriptome analysis of tomato (Solanum lycopersicum) in response to exogenous abscisic acid. BMC Genomics. 2013;14:841.

34. Peleg Z, Blumwald E. Hormone balance and abiotic stress tolerance in crop plants. Curr Opin Plant Biol. 2011;14(3):1290-5.

35. Ma Y, Szostkiewicz I, Korte A, Moes D, Yang Y, Christmann A, Grill E. Regulators of PP2C phosphatase activity function as abscisic acid sensors. Science. 2009;324(5930):1064-8.

36. Sang-Youl Park PF, Nishimura N, Jensen DR, Fujii H, Zhao Y, Lumba S, Rodrigues A, Tsz-fung F. Chow, et.al. Abscisic acid inhibits PP2Cs via the PYR/PYL family of ABA-binding START proteins. Science. 2009;324(5930): 1068-71.

37. Ghanem ME, Albacete A, Martinez-Andujar C, Acosta M, Romero-Aranda R, Dodd IC, Lutts S, Perez-Alfocea F. Hormonal changes during salinity-induced leaf senescence in tomato (Solanum lycopersicum L.). J Exp Bot. 2008;59(11): 3039-50.

38. Galvan-Ampudia CS, Testerink C. Salt stress signals shape the plant root. Curr Opin Plant Biol. 2011;14(3):296-302

39. Rowe JH, Topping JF, Liu J, Lindsey K. Abscisic acid regulates root growth under osmotic stress conditions via an interacting hormonal network with cytokinin, ethylene and auxin. New Phytol. 2016. doi:10.1111.

40. Xu WF, Jia LG, Baluska F, Ding GC, Shi WM, Ye NH, Zhang JH. PIN2 is required for the adaptation of Arabidopsis roots to alkaline stress by modulating proton secretion. J Exp Bot. 2012;63(17):6105-14.

41. Postma J, Liebrand TW, Bi G, Evrard A, Bye RR, Mbengue M, Kuhn H, Joosten $\mathrm{MH} 2$, Robatzek S. Avr4 promotes Cf-4 receptor-like protein association with the BAK1/SERK3 receptor-like kinase to initiate receptor endocytosis and plant immunity. New Phytol. 2016;210(2):627-42.

42. Hossain MA, Munemasa S, Uraji M, Nakamura Y, Mori IC, Murata Y. Involvement of endogenous abscisic acid in methyl jasmonate-induced stomatal closure in Arabidopsis. Plant Physiol. 2011;156(1):430-8.

43. Shiu SH, Bleecker AB. Plant receptor-like kinase gene family: diversity, function, and signaling. Sci STKE. 2001;2001:re22

44. Shiu SH, Bleecker AB. Expansion of the receptor-like kinase/Pelle gene family and receptor-like proteins in Arabidopsis. Plant Physiol. 2003;132:530-43.

45. Marshall A, Aalen RB, Audenaert D, Beeckman T, Broadley MR, Butenko MA, Cano-Delgado Al, de Vries S, Dresselhaus T, Felix G, et al. Tackling drought stress: receptor-like kinases present new approaches. Plant Cell. 2012;24(6): 2262-78.

46. Afzal AJ, Wood AJ, Lightfoot DA. Plant receptor-like serine threonine kinases: roles in signaling and plant defense. Mol Plant Microbe In. 2008;21(5):507-17.

47. Giranton JL, Dumas C, Cock JM, Gaude T. The integral membrane S-locus receptor kinase of Brassica has serine/threonine kinase activity in a membranous environment and spontaneously forms oligomers in planta. Proc Natl Acad Sci U S A. 2000;97:3759-64.

48. Humphrey TV, Haasen KE, Aldea-Brydges MG, Sun $H$, Zayed $Y$, Indriolo $E$, et al. PERK-KIPK-KCBP signalling negatively regulates root growth in Arabidopsis thaliana. J Exp Bot. 2015;66(1):71-83.

49. Silva NF, Goring DR. The proline-rich, extensin-like receptor kinase-1 (PERK1) gene is rapidly induced by wounding. Plant Mol Biol. 2002;50(4-5):667-85.

50. Li CH, Wang G, Zhao JL, Zhang LQ, Ai LF, Han YF, Sun Y. The receptor-like kinase SIT1 mediates salt sensitivity by activating MAPK3/6 and regulating ethylene homeostasis in rice. Plant Cell. 2014;26(6):2538-53.

51. Asai T, Tena G, Plotnikova J, Willmann MR, Chiu WL, Gomez-Gomez L, Boller T, Ausubel FM, Sheen J. MAP kinase signalling cascade in Arabidopsis innate immunity. Nature. 2002;415(6875):977-83.

52. Opdenakker K, Remans T, Vangronsveld J, Cuypers A. Mitogen-Activated Protein (MAP) kinases in plant metal stress: regulation and responses in comparison to other biotic and abiotic stresses. Intl J Mol Sci. 2012;13(6):7828-53.
53. Wurzinger B, Mair A, Pfister B, Teige M. Cross-talk of calcium-dependent protein kinase and MAP kinase signaling. Plant Signal Behav. $2011 ; 6(1): 8-12$.

54. Luan S, Kudla J, Rodriguez-Concepcion M, Yalovsky S, Gruissem W. Calmodulins and calcineurin B-like proteins: calcium sensors for specific signal response coupling in plants. Plant Cell. 2002;14(Suppl):S389-400.

55. Isope P, Wilms CD, Schmidt H. Editorial: determinants of synaptic information transfer: from $\mathrm{Ca}^{2+}$ binding proteins to $\mathrm{Ca}^{2+}$ signaling domains. Front Cell Neurosci. 2016;10:69. doi:10.3389.

56. Campo S, Baldrich P, Messeguer J, Lalanne E, Coca M, San SB. Overexpression of a calcium-dependent protein kinase confers salt and drought tolerance in rice by preventing membrane lipid peroxidation. Plant Physiol. 2014;165(2):688-704.

57. Nakano T, Suzuki K, Fujimura T, Shinshi H. Genome-wide analysis of the ERF gene family in Arabidopsis and rice. Plant Physiol. 2006;140:411-32.

58. Chen YH, Yang XY, He K, Liu MH, Li JG, Gao ZF, Lin ZQ, Zhang YF, Wang XX, et al. The MYB transcription factor superfamily of Arabidopsis: Expression analysis and phylogenetic comparison with the rice MYB family. Plant Mol Biol. 2006;60:107-24

59. Zhang LC, Zhao GY, Jia JZ, Liu X, Kong XY. Molecular characterization of 60 isolated wheat MYB genes and analysis of their expression during abiotic stress. J Exp Bot. 2012;63(1):203-14.

60. Dong JX, Chen $\mathrm{CH}$, Chen ZX. Expression profiles of the Arabidopsis WRKY gene superfamily during plant defense response. Plant Mol Biol. 2003;51(1):21-37.

61. Busch W, Wunderlich M, Schoffl F. Identification of novel heat shock factor-dependent genes and biochemical pathways in Arabidopsis thaliana. Plant J. 2005:41(1):1-14.

62. Morita H, Wanibuchi K, Nii H, Kato R, Sugio S, Abe I. Structural basis for the one-pot formation of the diarylheptanoid scaffold by curcuminoid synthase from Oryza sativa. Proc Natl Acad Sci U S A. 2010;107(46):19778-83.

63. Abe I, Morita H. Structure and function of the chalcone synthase superfamily of plant type III polyketide synthases. Nat Prod Rep. 2010;27(6):809-38

64. Farrow SC, Facchini PJ. Dioxygenases catalyze O-demethylation and O, Odemethylenation with widespread roles in benzylisoquinoline alkaloid metabolism in opium poppy. J Biol Chem. 2013;288(40):28997-9012.

65. Grabherr MG, Haas BJ, Yassour M, Levin JZ, Thompson DA, Amit I, Adiconis X, Fan L, Raychowdhury R, Zeng Q, et al. Full-length transcriptome assembly from RNA-Seq data without a reference genome. Nat Biotechnol. 2011;29:644-52

66. Pertea G, Huang X, Liang F, Antonescu V, Sultana R, Karamycheva S, Lee Y, White J, Cheung F, Parvizi B, et al. TIGR Gene Indices clustering tools (TGICL): a software system for fast clustering of large EST datasets. Bioinformatics. 2003;19:651-2.

67. Conesa A, Gotz S, Garcia-Gomez JM, Terol J, Talon M, Robles M. Blast2GO: a universal tool for annotation, visualization and analysis in functional genomics research. Bioinformatics. 2005;21:3674-6.

68. Mortazavi A, Williams BA, McCue K, Schaeffer L, Wold B. Mapping and quantifying mammalian transcriptomes by RNA-Seq. Nat Methods. 2008:5:621-8.

69. Audic S, Claverie JM. The significance of digital gene expression profiles Genome Res. 1997;7(10):986-95.

70. Zhang X, Liao M, Chang D, Zhang F. Comparative transcriptome analysis of the Asteraceae halophyte Karelinia caspica under salt stress. BMC Res Notes. 2014;7:927.

\section{Submit your next manuscript to BioMed Central and we will help you at every step:}

- We accept pre-submission inquiries

- Our selector tool helps you to find the most relevant journal

- We provide round the clock customer support

- Convenient online submission

- Thorough peer review

- Inclusion in PubMed and all major indexing services

- Maximum visibility for your research

Submit your manuscript at www.biomedcentral.com/submit 